\title{
Treasury Inc.: How the Bailout Reshapes Corporate Theory and Practice
}

\author{
J.W. Verret ${ }^{\dagger}$
}

Corporate law theory and practice considers shareholder relations with companies and the implications of ownership separated from control. Yet through the Troubled Asset Relief Program (TARP) bailout and the government's resultant shareholding, ownership and control at many companies have merged, leaving corporate theory and practice for the financial and automotive sectors in chaos. The government's $\$ 700$ billion bailout is a unique historical event; not merely because of its size, but also because of a resulting ripple through corporate scholarship and practice. This Article builds on the Author's five testimonies before Congress during the financial crisis and implementation of the TARP bailout and his consultation for the Special Inspector General for TARP. It updates the six central theories of corporate law to reveal that none function adequately when considered with a controlling government shareholder that enjoys sovereign immunity from corporate and securities law. From agency theory and nexus-ofcontracts thought to the shareholder/director primacy debate, even to notions of progressive corporate law, existing theory breaks down when a government shareholder is present. After considering corporate theory, the Article offers predictions for how the Treasury Department's stock ownership reshapes the practice of corporate law. In short, TARP will result in a tectonic shift for current understanding about insider trading, securities class actions, share voting, and state corporate law fiduciary duties. The Article closes with three recommendations. First, that the Treasury take frozen options, an invention explained in the text, rather than equity. Second, that Congress pass

\footnotetext{
$\uparrow$ Assistant Professor of Law, George Mason University School of Law; Senior Scholar, Mercatus Center Financial Markets Working Group. This Article is informed by the Author's five appearances in Congress testifying before the House Committee on Oversight, the House Committee on Financial Services, and the Senate Committee on Banking, Housing, and Urban Development during 2009. It is also informed by the Author's work as a consultant for the Treasury Department's Special Inspector General for the Troubled Asset Relief Program (TARP) bailout. This Article has informed the TARP Recipient Ownership Trust Act of 2009, introduced by Senator Bob Corker and Senator Mark Warner. I appreciate helpful comments from Richard Epstein, Jonathan Macey, Roberta Romano, and other participants at the NYU Law School Federalist Society Roundtable on Securities Regulation; Henry Butler, Richard Booth, and other participants at the Northwestern University School of Law Searle Center Research Roundtable on Corporate Governance; and Bruce Johnsen, Steve Eagle, Bruce Kobayashi, Lloyd Cohen, Eric Claeys, Todd Zywicki, Adam Mossoff, and other participants at the George Mason University (GMU) Levy Center Workshop. I acknowledge support from the Corporate Federalism Initiative at GMU Law School and the GMU Law School Center for Law and Economics.
} 
legislation establishing a fiduciary duty for the Treasury to maximize the value of its investment, a suggestion that has informed language drafted in legislation introduced by Senator Mark Warner and Senator Bob Corker. And finally, that the Treasury adopt a sales plan for closing out its TARP holdings.

Introduction. 285

I. History of Company Ownership by the Federal Government .................... 289

11. The Troubled Asset Relief Program ................................................................ 294

III. The Federal Government as Control Shareholder.................................... 299

IV. Shareholder Control Meets Sovereign Immunity ....................................... 307

V. Implications for Corporate Law Theory ....................................................... 315

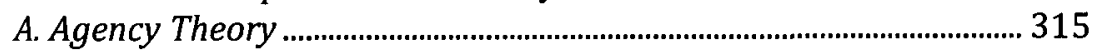

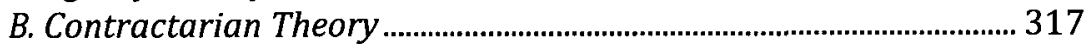

C. Shareholder Primacy Theory ............................................................... 318

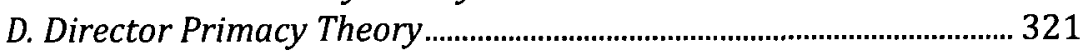

E. Team Production Theory........................................................................... 321

F. Progressive Corporate Law Theory ..................................................... 323

VI. Implications for Corporate and Securities Practice .................................... 326

A. TARP Recipients Treated as Affiliates Under Securities Laws........ 326

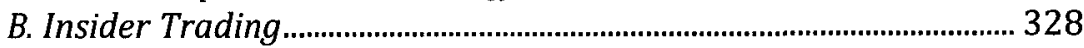

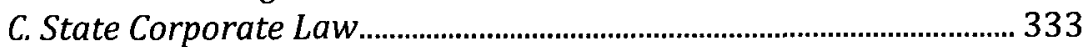

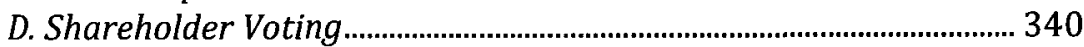

E. Securities Class Actions .......................................................................... 341

VII. Proposed Solutions........................................................................................ 344

A. Fiduciary Duties for the Federal Government as Shareholder ....... 345

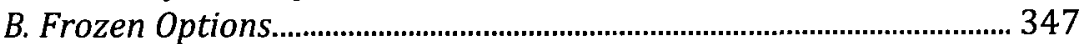

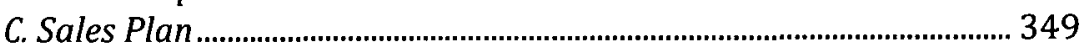


The good and efficient working of a board of Bank Directors depends on its internal harmony.... In France the difficulty... has been met characteristically. The Bank of France keeps the money of the State, and the State appoints its Governor. The French have generally a logical reason to give for all they do, though perhaps the results of their actions are not always so good as the reasons for them. The [Governor] has not always, I am told, been a very competent person.

Walter Bagehot, first Editor-in-Chief of The Economist, $1873^{1}$

Introduction

The theory and practice of corporate and securities law in the United States is a carefully constructed tapestry, woven through the time span of the American experience. Over that time, the expectations of investors, managers, and regulators have enjoyed a dance of slow experimentation toward a steady and predictable evolution. The thesis of this Article is that when the Treasury Department ("Treasury") and the Federal Reserve ("Fed"), through the Troubled Asset Relief Program (TARP) bailout, took equity positions in over six hundred of the nation's banks, as well as in the American International Group (AIG), Fannie Mae, Freddie Mac, GM, Chrysler, and GMAC, they introduced an entirely alien variable to this finely woven tapestry.

There are two foundations underlying this observation. First, the Treasury and the Fed are generally controlling shareholders, even in spite of their relatively low minority interest in particular companies. Second, they are controlling shareholders that also enjoy sovereign immunity from federal securities law and state corporation law. The presence of a control shareholder in publicly traded corporations is relatively infrequent. The presence of a control shareholder in publicly traded companies that also enjoys sovereign immunity from corporate and securities law is entirely novel. As a result of this perfect storm, a thorough investigation of the implications of the government's ownership via TARP reveals a number of uniquely unforeseen consequences to the theory and practice of corporate and securities law.

To emphasize the unique nature of the Treasury's ownership through TARP, this Article will begin by briefly considering the history of the United States government's entanglement in private business. Though the federal government has frequently chartered businesses that were wholly owned by the United States, particularly during the Second World War, and

1 WALTER Bagehot, LOMBaRd STREeT: A DESCRIPTION OF THE MONEY MARKET 216-17 (14th ed. John Murray 1931) (1873). 
occasionally exercised power over publicly traded businesses through special provisions in their charters, as in the case of Fannie Mae and Freddie Mac, the United States government has never taken a controlling interest in a publicly traded company chartered under state law. As such, the government's ownership in businesses through TARP is a circumstance without precedent.

The emphasis of this Article is the revolutionary problems for corporate law theory and practice posed by the presence of a controlling shareholder that also enjoys sovereign immunity. Therefore, before rethinking those theoretical and practical elements, this Article will wade into these unexplored depths to consider the two threshold questions in the analysis. First, is the government really a controlling shareholder? And second, do the Treasury and Federal Reserve actually enjoy sovereign immunity from corporate and securities law?

One answer this Article proposes is that the government is likely a control shareholder for the largest TARP recipients in which it holds an interest, including Citigroup ("Citi"), AIG, GM, Fannie Mae, Freddie Mac, and, with some significant measure of certainty, the nine remaining banks from among the top nineteen banks to originally receive TARP funding. This Article then offers the suggestion that the government might, with a steadily decreasing degree of certainty based on degree of government ownership, also be considered a control shareholder for many of the other six hundred banks accepting TARP funding.

This Article then considers the application of sovereign immunity to the Treasury and Federal Reserve's exercise of ownership in TARP companies under the bailout, and suggests a number of novel theories under which a clever plaintiff's lawyer might try to challenge the federal government's sovereign immunity. It ultimately arrives at the conclusion that the federal government's belt-and-suspenders approach protecting it from liability in this arena, including the liability waivers of the Emergency Economic Stability Act (EESA), ${ }^{2}$ waivers included in the Securities Exchange Act (the "34 Act" or the "Exchange Act"), and challenges to using other avenues, eventually forecloses meaningful challenge to the federal government's sovereign immunity in its exercise of ownership power over its TARP shares.

Thus, the first prong of this Article's thesis is that the theoretical underpinnings of American corporate law are completely unprepared for the presence of a control shareholder with sovereign immunity. This is a fairly unique outcome. Corporate law theory is home to essentially six distinct, and at times vigorously opposed, schools of thought that do battle in the arena of corporate theory. First, this Article looks to the foundations

2 Emergency Economic Stabilization Act of 2008, Pub. L. No. 110-343, div. A, 122 Stat. 3765 (to be codified in scattered sections of 12 U.S.C.). 
of corporate law in agency theory and nexus-of-contracts theory. In both contexts, it considers the effects of a control shareholder with sovereign immunity. Then, it considers the Cain and Abel-like warring children of the agency and nexus-of-contracts marriage: shareholder primacy and director primacy. Shareholder primacy is a difficult fit, as it contemplates a nonconflicted shareholder electorate that minimizes the special interest director problem, a washboard which TARP ownership obviously complicates. Director primacy is an easy critic of TARP ownership, as it is inherently hostile to the accretion of shareholder power, and yet is difficult to understand in light of elected directors who may be beholden to government shareholders.

The team production model of corporate law is also considered in this Article, with the result that the model's reliance on the board of directors as a mediating hierarch, balancing the interests of varying stakeholders, is complicated by the political pressures placed on the government shareholder hierarch in this situation. The progressive corporate law model of corporate law is also considered in light of this dynamic, with the result that the accountability of government regulators and the disclosure rules underlying progressive corporate law are threatened by the presence of government ownership.

In the final analysis, this Article considers each of the central theories of corporate law in turn, and in depth, with updated analysis that considers the presence of an immune control shareholder, and arrives at the conclusion that none of these central corporate law theories supports, or even properly describes, the propriety or effect of a controlling shareholder that at once enjoys sovereign immunity and regulates the businesses in which it holds an interest.

Near the close of the inquiry, this Article then enters the second prong of its thesis by offering some analysis for practitioners of corporate and securities law with a warning about the effect of the Treasury as a shareholder. In short order, it warns that 1) the Treasury has free reign to engage in insider trading of its shares, 2) the Treasury is the only control shareholder that evades fiduciary duties to other shareholders under corporate law, 3) the Treasury may end up serving as a lead plaintiff in private securities class action litigation against the very companies it is trying to support through TARP, 4) sales of unregistered securities of any TARP recipient held by another TARP recipient may be considered affiliated sales, which means they might be voidable at the option of any shareholder that purchases them, 5) the ability of boards of directors to approve conflicted transactions, which hinges on their independence under state corporate law, may be endangered, and 6) the government will obtain the right to nominate candidates for the boards of publicly traded companies, and vote for other shareholders' nominees, under a pending 
rule from both the SEC and the Congress designed to facilitate shareholder access to the corporate ballot.

In concluding, the Article offers a touch of hope to the concerned corporate law traditionalist in the form of three unique reform suggestions. First, it recommends that the government eschew its voting common equity, and even its non-voting preferred shares, in favor of frozen options. Those options would be designed such that the government would never be permitted to exercise them, and accordingly never be permitted to exercise the voting or other rights that accompany either common or preferred shares. The government, however, would be permitted to sell them into the market and allow other non-governmental shareholders to exercise the options and exercise all the rights that would accompany the form of shares into which those temporarily frozen (only in government hands) options would morph. This should serve as a significant buffer to the analysis that the federal government holds a control position in TARP companies, which is so central to this Article's analysis concerning the resultant complications for corporate theory and practice.

Second, in conjunction with, or even despite an absence of, the frozen shares recommendation, this Article recommends that the Treasury and the Federal Reserve set up trusts to hold their ownership that create an explicit obligation for those entities to maximize long-term shareholder wealth in the invested TARP companies. This would be accompanied by a waiver of the federal government's sovereign immunity with respect to state corporate law, as well as a waiver of its immunity under section 3(c) of the Exchange Act and attendant immunity provisions of the EESA.

Third, also in conjunction with (or despite a lack of) the preceding recommendations, this Article suggests that the federal government as a shareholder should execute a Rule $10 \mathrm{~b}-5$ trading plan similar to the type filed by executives to protect against liability for insider trading. This plan should be binding on the Treasury by law, with appropriate ranges of trade amounts to leave a reasonable measure of discretion for Treasury bureaucrats on each trading date, to minimize the threat of insider trading by the Department and cement a near-term exit date for the government from its positions in private businesses.

The issues presented in this Article are far more than theoretical exercises. The theory and practice of corporate and securities law governs the exercise of power in the securities market. The average American, either directly through his or her holdings in mutual funds, or derivatively as a beneficiary of public or private pension funds, enjoys the lion's share of profits and losses in that market. Careful attention must be paid to any overriding force, such as the government's ownership via the bailout, which disrupts the order and evolution of that market. The federal government's position as the dominant shareholder in the financial services and automotive sectors requires careful consideration of its 
shareholder rights. Governments are a unique brand of shareholder. Without forethought about how those shareholder rights and responsibilities will be managed, the unintended consequences to capital markets could be dramatic.

\title{
I. History of Company Ownership by the Federal Government
}

Government ownership of corporations is not without precedent in the United States. Amtrak, for instance, is a government-owned company. ${ }^{3}$ The first government-created business in the United States was the Bank of the United States, created by a congressional action in 1791, which authorized the United States to own twenty percent of the bank corporation's stock. ${ }^{4}$ Lebron v. National Railroad, a 1995 Supreme Court case, states "[T]he Federal Government continued to charter private corporations" for the next century, such as the Northern Pacific Railroad Company, "but only once participated in such a venture itself: the Union Pacific Railroad, chartered in 1862 with the specification that two of its directors would be appointed by the President of the United States." 5

3 See Lebron v. Nat'l R.R. Passenger Corp., 513 U.S. 374, 385-86 (1995) (summarizing the status of Amtrak and the history of government-owned corporations in the United States). As Lebron chronicled:

\begin{abstract}
Amtrak is incorporated under the District of Columbia Business Corporation Act, D.C. CODE ANN. $§ 29-301$ et seq. (1981 \& Supp. 1994), but is subject to the provisions of that Act only insofar as the [Rail Passenger Service Act (RPSA)] [which created it] does not provide to the contrary, see $\$ 541$. It does provide to the contrary with respect to many matters of structure and power, including the manner of selecting the company's board of directors. The RPSA provides for a board of nine members, six of whom are appointed directly by the President of the United States. The Secretary of Transportation, or his designee, sits ex officio. $\$ 543(a)(1)(A)$. The President appoints three more directors with the advice and consent of the Senate, $\S 543(\mathrm{a})(1)(\mathrm{C})$.... The President appoints two additional directors without the involvement of the Senate, choosing them from a list of names submitted by various commuter rail authorities. $\$ 543(\mathrm{a})(1)$ (D) ... . The holders of Amtrak's preferred stock select two more directors, who serve 1-year terms. $\$$ $543(a)(1)(E)$. Since the United States presently holds all of Amtrak's preferred stock, which it received (and still receives) in exchange for its subsidization of Amtrak's perennial losses, see $\S 544(\mathrm{c})$, the Secretary of Transportation selects these two directors. The ninth member of the board is Amtrak's president, $\S 543(\mathrm{a})(1)(\mathrm{B})$.
\end{abstract}

Lebron, 513 U.S. at 385.

$4 \quad$ Id. at 386-87. "That Bank expired pursuant to the terms of its authorizing Act 20 years later. A second Bank of the United States, the bank of McCulloch v. Maryland," was later created by a bill providing that the United States would own twenty percent of its stock, and the "President would appoint, by and with the advice and consent of the Senate, 5 of the Bank's 25 directors, the rest to be elected annually by shareholders other than the United States." Id. That bank's charter also expired in 1836. Id. at 387. See generally Richard W. Painter, Ethics and Corruption in Business and Government: Lessons from the South Sea Bubble and the Bank of the United States (Minnesota Legal Studies Research Paper No. 06-32, 2006), available at http://papers.ssrn.com/sol3/papers.cfm?abstract_id=920912.

5 Lebron, 513 U.S. at 387 (citation omitted). 
Congress, in 1902, facilitated the construction of the Panama Canal by authorizing presidential purchases of "the assets of the New Panama Canal Company of France, including that company's stock holdings in the Panama Railroad Company, a private corporation chartered in 1849 by the State of New York." 6 The United States thus became "the sole shareholder of the Panama Railroad, and continued to operate it under its original charter, with the Secretary of War, as the holder of the stock, electing the Railroad's 13 directors." 7

It was during the First World War that "large-scale use of Government-controlled corporations" 8 began. But it was during the Great Depression that government corporations truly came into the limelight, guided by the goal of stabilizing the economy and making distress loans to farms, homeowners, banks, and other enterprises. ${ }^{9}$ To offer one eerie echo of the past, the Reconstruction Finance Corporation (RFC) was created to make loans to banks, insurance companies, railroads, land banks, and agricultural credit organizations, including loans secured by the assets of failed banks, sharing a nearly identical driving goal to that of the TARP program. ${ }^{10}$

The RFC sought to execute its authority by forming a number of corporations, at times under state law and at times under federal charter. ${ }^{11}$ Once the Second World War ended, government involvement in corporations had become widespread, and concerns about their accountability led to calls for the government to rein in government

6 Id. (citing Act of June 28, 1902, Pub. L. No. 57-183, 32 Stat. 481); see also GEN. ACCOUNTING OFFICE, REFERENCE MANUAL OF GOVERNMENT CORPORATIONS, S. DOC. No. 79-86, at 176 (1945) [hereinafter GAO CORPORATION MANUAL].

7 Lebron, 513 U.S. at 387 (citing JOINT COMM. ON REDUCTION OF NONESSENTIAL FED. EXPEndituRes, REDUCTION OF NONESSENTIAL FEdERAL EXPENDITURES, S. DOC. No. 78-227, at 20 (1944)).

8 Lebron, 513 U.S. at 388. "In 1917 and 1918, Congress created, among others, the United States Grain Corporation, the United States Emergency Fleet Corporation, the United States Spruce Production Corporation, and the War Finance Corporation," none of which were publicly traded and all of which were also dissolved after the war. $I d$.

9 Id. (citing R. Moe, CRS Report For Congress, Administering Public Functions at the MARgins OF GOVERNMENT: THE CASE OF FEDERAL CORPORATIONS 6-7 (1983)).

10 Lebron, 513 U.S. at 388 (noting that a few corporations, such as the Tennessee Valley Authority (TVA), brought the government into the commercial sale of goods and services); see also Act of May 18, 1933, ch. 32, 48 Stat. 58 (codified as amended at 16 U.S.C. $\S \S 831-831$ ee (2006)).

11 See Lebron, 513 U.S. at 388-89. "In 1940, Congress empowered the RFC to create corporations without specific congressional authorization." Id. at 388. For example, the RFC created the Defense Plant Corporation, the Defense Supplies Corporation, the Metals Reserve Company, the Petroleum Reserves Corporation, the Rubber Development Corporation, and the War Damage Corporation, among others. See GAO CORPORATION MANUAL, supra note 6, at 32, 38, 169, 182, 219, 279; see also Lebron, 513 U.S. at 389 ("Other corporations were formed, sometimes under state law, without even the general congressional authorization granted the RFC. For example, the Defense Homes Corporation was organized under Maryland law by the Secretary of the Treasury, using emergency funds allocated to the President . . . and the Tennessee Valley Associated Cooperatives, Inc., was chartered under Tennessee law by the TVA. By 1945, the General Accounting Office's Reference Manual of Government Corporations listed 58 Government corporations, with total assets (in 1945 dollars) of $\$ 29.6$ [billion]."). 
corporations. ${ }^{12}$ Congress then passed the Government Corporation Control Act (GCCA). ${ }^{13}$ One of the more important provisions of the GCCA for our purposes was that it "ordered the dissolution or liquidation of all government corporations created under state law, except for those that Congress should act to reincorporate; and prohibited creation of new Government corporations without specific congressional authorization." 14

In the 1960s new corporate entities were formed. Many of them were merely government agencies located within the existing Government structure. ${ }^{15}$ Starting in 1962, however, the Government began sponsoring corporations that were not designated as arms of the federal government under the GCCA. The first of these corporations, "the Communications Satellite Corporation (Comsat), was incorporated under the District of Columbia Business Corporation Act."16 Comsat was entirely privately capitalized. ${ }^{17}$ In sharp relief against its counterparts "that had in the past been deemed part of the Government, Comsat's board was to be controlled by its private shareholders; only 3 of its 15 directors were appointed by the President." 18

The Comsat model was explicitly created with the purpose of permitting a private company to raise private capital, while also enjoying preferential treatment from the government at the same time. ${ }^{19}$ The government soon followed in creating other corporations, nearly all of which were under the direct control of the federal government and none of which were publicly traded. ${ }^{20}$

The final noteworthy examples of government-owned corporations are Fannie Mae ("Fannie") and Freddie Mac ("Freddie"). Both were government-chartered but shareholder-owned and publicly traded

12 See Lebron, 513 U.S. at 389-90.

13 See id. (citing Government Corporation Control Act, 59 Stat. 597 (codified as amended at 31 U.S.C. $\$ \S 9101-9110$ (2006)). "The GCCA required that specified corporations, both wholly owned and partially owned by the Government, be audited by the Comptroller General. Additionally, the wholly owned corporations were required, for the first time, to submit budgets which would be included in the budget submitted annually to Congress by the President." Id. (citing FRANCES J. LEAZES, JR,, ACCOUNTABILITY AND THE BUSINESS STATE 22-23 (1987)).

14 Id. Justice Scalia also notes in Lebron that "in the years immediately following World War II, many Government corporations were dissolved, and to our knowledge only one, the Saint Lawrence Seaway Development Corporation, was created." Id.

15 See id.

16 See id. Comsat was created with the express purpose of entering the private sector, but doing so with government-conferred advantages. See MOE, supra note 9, at 22.

17 See Lebron, 513 U.S. at 390 (citing Harold Seidman, Government-Sponsored Enterprises in the United States, in The New Political Economy: The Public Use of THE PRIVATe Sector 92 (B. Smith ed., 1975)).

18 See id. at 390-91 (citing 47 U.S.C. $\$ 733(a)(1994)$ ).

19 See id. at 391 (citing MoE, supra note 9, at 22, 24).

20 Id. ("But some of these new 'private' corporations, though said by their charters not to be agencies or instrumentalities of the Government, and though not subjected to the restrictions of the GCCA, were (unlike Comsat) managed by boards of directors on which Government appointees had not just a few votes but voting control."). 
companies. $^{21}$ In one part of their business, they would aggregate mortgages into pools and sell interests in the pools, known as mortgage backed securities (MBS). 22 They would guarantee the credit risk on those mortgages, or the risk that the mortgage holders would default, for roughly $\$ 2$ trillion of such mortgages. ${ }^{23}$ As of 2008 , they guaranteed roughly $\$ 3.7$ trillion in liabilities. This growth was substantial, particularly compared to $\$ 2.9$ trillion in all outstanding corporate bonds and $\$ 4.4$ trillion in outstanding Treasury debt trading at the time.

Fannie and Freddie present an interesting case study for how government-owned firms are managed, and how they are perceived by the market. The Treasury did not own an equity interest in Fannie and Freddie until it recently placed them under conservatorship after the prospect of their insolvency had arisen. ${ }^{24}$ The President did however have the ability, written into Fannie and Freddie's charters, to place directors on the board, which through voting is also one of the central powers granted to stockholders. The federal government also implicitly guaranteed the debts of Fannie and Freddie, which makes the comparison to TARP banks all the more useful since the Treasury's capital injections and equity holdings in TARP banks have also been accompanied by a debt guarantee, and governments universally tend to continue to guarantee debts of companies in which they hold an equity interest. 25

From its creation until the government sold its shares in Comsat to Lockheed Martin, Comsat was a publicly traded corporation. In effect, it is probably the one example from modern history that comes close to the unique aspects of the Treasury's TARP holdings, namely government controlling ownership in a publicly traded, state-incorporated company. Yet the full implications of this fact never truly developed in the Comsat example due the government's short tenure as owner. The federal

21 See Peter J. Wallison, Am. Enter. Inst. for Pub. Policy Research, Regulating fannie MAE AND FREDDIE MAC: NOW IT GETS SERIOUS (2005), available at http://www.aei.org/docLib/20050513_FSOMay_g.pdf.

22 Id.

23 See id. They would also hold some of the MBS in their own portfolios, thus holding both the credit risk and the interest rate risk associated with the mortgages, and attempt to hedge those risks through other transactions. This accounted for another $\$ 1.5$ trillion.

24 Peter J. Wallison, Private Profits, Public Risks, WALL ST. J., Mar. 24, 2008, at A19. Congress oversaw a regulator created to oversee only the two government-sponsored enterprises (GSEs). Fannie and Freddie were originally chartered by Congress as federal agencies, but were later privatized by a sale of equity in their operations to private shareholders in order to ensure that their purchases and sales of mortgages could be removed from the federal budget. Members of Congress expected Fannie and Freddie to subsidize low-income borrowers.

25 Peter J. Wallison, Am. Enter. Inst. for Pub. Policy Research, Moral hazard on STERoIDS: THE OFHEO REPORT SHOWS THAT REgulation CANNOT PROTECT U.S. TAXPayerS (2006), available at http://aei.org/docLib/20060623_20284FSOJuly2006_g.pdf. 
government did not own any common shares in the other close analogues to TARP, Fannie Mae and Freddie Mac. ${ }^{26}$

Despite a rich history of government involvement in creating business and privatizing government functions as business, there is no precedent for the unique confluence of factors for those businesses that have taken TARP funding in exchange for giving the government an ownership, and often controlling, stake. We find no example from among this rich history in which the government owned a controlling stake in a publicly traded business incorporated under state law. That unique fact is the wellspring for the thesis of this Article, that the architecture of corporate and securities law is unprepared for the theoretical and mechanical challenges that accompany government ownership in private businesses.

One may argue that temporary government ownership to facilitate bank liquidation, for instance the authority frequently used by the Federal Deposit Insurance Corporation (FDIC), should also be considered government ownership of private business. Bank nationalization can come in two distinct forms. It can be short-term, dedicated solely to the orderly windup of a bank's assets, as in the FDIC's process for winding up failed banks that are FDIC insured or the creation of the Resolution Trust Corporation to deal with the savings and loan crisis of the early 1990s. The second possibility is a long-term period of government ownership designed to alter the lending policies of a bank. It remains to be seen whether the second form of nationalization accurately characterizes the government's holdings in the financial sector under TARP.

Thus the government's ownership of private business is not without precedent. And yet, the complications that the government's ownership through TARP present are entirely novel. First, as the vast majority of these examples were created by government charter, they would not be subject to fiduciary duty laws that apply to state-chartered companies under state corporate law. The situation of government-controlled shareholders being exempt from fiduciary principles while all the other shareholders in the company are not, analyzed in this Article, would not be present. Second, the government-chartered corporations were not created with the intent of subsequently divesting the government of any ownership or power over the companies they own, which is not true for the government's ownership under TARP. As a result, a number of entirely novel complications arise for corporate and securities laws from the government's TARP ownership. This Article offers some initial analysis of these complications.

26 One distinction, of course, is that Comsat, Fannie Mae, and Freddie Mac were all originally created by the government, whereas most of the TARP firms were not. 


\section{The Troubled Asset Relief Program}

In response to a dramatic credit freeze that put unprecedented pressure on financial institutions in late 2008, the U.S. government initiated a $\$ 700$ billion bailout of the financial industry that mainly consisted of the Treasury purchasing equity in troubled banks under the TARP. In order to execute its mandate under the EESA to ensure the health of the nation's banking system, the Treasury Department purchased controlling interests in hundreds of the nation's largest banks, GM and Chrysler, as well as the insurance conglomerate AIG, and GMAC, the financing arm of GM.

As part of that bailout, the Treasury took preferred shares, and subsequently initiated a plan to convert those non-voting preferred shares into shares convertible into voting common equity in banks participating in TARP. The Treasury's initial experiment in holding common equity took place at Citigroup, in which it took a controlling $34 \%$ voting stake.

The original plan for the TARP program was for the government to use the $\$ 700$ billion authorized under the EESA to buy and sell troubled assets. ${ }^{27}$ That plan was quickly shelved, and the Treasury Department immediately began a number of different programs. I will omit description of some of the programs falling under TARP, and focus only on those directly linked to the government's accepting equity positions in return for its injections of TARP capital.

Under the Capital Purchase Program (CPP), the Treasury made investments in six hundred forty-nine banks of $\$ 203$ billion, of which eight institutions received a total of $\$ 134$ billion. ${ }^{28}$ As of April 2010, $\$ 70$ billion of that has since been repaid. Through the Targeted Investment Program (TIP), the government invested an additional $\$ 40$ billion in Citigroup and Bank of America. ${ }^{29}$ The CPP is the central link to the Treasury's equity investment in the financial sector. Of the $\$ 203$ billion it spent, $\$ 25$ billion went to each of Bank of America, Citigroup, JPMorgan, and Wells Fargo. ${ }^{30}$ Another $\$ 10$ billion went to each of Goldman Sachs and Morgan Stanley. ${ }^{31}$ When combined with the TIP, the federal government's investment in Bank of America and Citigroup becomes $\$ 45$ billion each. ${ }^{32}$ Initially recipients under the CPP were not permitted to buy back their shares for three years, but that was modified by the American Recovery and Reinvestment Act of

27 OfFice of THE SPECIAL INSPECTOR Gen. FoR THE TROUbled AsSet Relief Program, QUARTERLY REPORT TO CONGRESS 3 (July 21, 2009) [hereinafter SIGTARP QUARTERLY REPORT].

28 Id. at 4.

29 Id.

$30 \quad$ Id. at 38.

31 Id.

32 Id. 
2009 to permit banks to buy back their CPP shares in consultation with their banking regulator. ${ }^{33}$

Under the initial terms of the CPP, banks receiving capital injections gave the government preferred shares with a $5 \%$ dividend for five years, which then increased to $9 \%$ after five years, and warrants to purchase additional common shares. ${ }^{34}$ Participants in the CPP may redeem the preferred shares at face value after three years. ${ }^{35}$ In addition, the Treasury may sell them at any time. ${ }^{36}$ Valuing the government's TARP shareholdings is tricky, owing to the nature of the credit market freeze-up and problems in marking MBS and credit default obligation (CDO) assets to market. However, for our purposes considering them at cost will give some idea of the scale of shareholdings.

The second major industry supported under the TARP program is the automotive industry, in particular Chrysler, GM, Chrysler Financial, and GMAC. GM has been the beneficiary of $\$ 49.5$ billion under TARP, Chrysler $\$ 14.9$ billion, GMAC $\$ 13.4$ billion, and Chrysler Financial $\$ 1.5$ billion. ${ }^{37}$ Currently all of the shares in the reconstituted GM, after its emergence from bankruptcy, are owned by the U.S. government $(60 \%)$, the Canadian government $(12 \%)$, former bondholders (10\%), and the GM health care trust $(18 \%) .{ }^{38}$ The reconstituted $\mathrm{GM}$ is not publicly held, and as the major theories of corporate law discussed in this Article apply to widely held companies (and not privately held ones), GM would not be a good example for that analysis. In the event that GM is publicly listed while the U.S. government remains a shareholder, as is currently anticipated, that would change. Further, the private bondholders and the health care shareholders will still expect fiduciary duties from the government as the controlling shareholder, and in some jurisdictions those fiduciary duties are stronger for privately held companies than for publicly held companies. ${ }^{39}$

The Treasury Department's statement on the GM restructuring says that it intends to manage its investment in Citigroup in a "hands-off, commercial manner." 40 The Treasury published a white paper regarding its ownership in GM in which it offered four key principles for how it would try to minimize political influence in GM's operations, and yet there is no

$\begin{array}{ll}33 & \text { Id. at } 48 . \\ 34 & \text { Id. } \\ 35 & \text { Id. } \\ 36 & \text { Id. } \\ 37 & \text { Id. at } 94 .\end{array}$

38 Press Release, U.S. Dep't of the Treasury, FinancialStability.gov Fact Sheet: Obama Administration Auto Restructuring Initiative, General Motors Restructuring (June 1, 2009), http://www.financialstability.gov/latest/05312009_gm-factsheet.html [hereinafter Auto Restructuring Fact Sheet].

39 See, e.g., Donahue v. Rodd Electrotype Co., 328 N.E.2d 505 (Mass. 1975).

40 Auto Restructuring Fact Sheet, supra note 38. 
mechanism by which those principles can be enforced by a third party, nor are there any penalties for their violation. ${ }^{41}$

On March 30, 2009, the President's Auto Task Force determined that Chrysler's restructuring plan was not likely to permit it to emerge from bankruptcy, and pressured Chrysler to arrange a merger deal with Fiat. ${ }^{42}$ The U.S. government also took an $8 \%$ stake in Chrysler in exchange for its loan, but Fiat took a $20 \%$ stake and the United Auto Workers Health Care Trust took a $55 \%$ stake. 43

The Treasury Department obtained a 35\% ownership stake in GMAC from GM. ${ }^{44}$ GMAC is a provider of automobile financing spun off from GM. The government has announced its intention to use GMAC to promote the financing, and therefore the purchases, of automobiles from companies taking TARP funding. 45

The government also invested another $\$ 70$ billion in AIG through the Systemically Significant Failing Institutions Program. ${ }^{46}$ Under the Making Home Affordable Program, the Treasury offered to use nearly $\$ 50$ billion in TARP funding, in conjunction with at least $\$ 200$ billion from the Federal Reserve, to support Fannie and Freddie, both of which are now wholly owned by the federal government under conservatorship. ${ }^{47}$ Citigroup also received generous support by way of a $\$ 5$ billion TARP investment to support an asset guarantee program supporting \$301 billion in Citigroup's troubled assets. ${ }^{48}$ Various other TARP loan programs provide for asset guarantees and auto warranty guarantees for other companies, many of which took part in the programs described thus far.

Treasury Secretary Timothy Geithner announced a sweeping change to the TARP program on February 25, 2009.49 He announced that all banks with over $\$ 100$ billion in assets would be subject to stress testing. He also announced that the CPP would be replaced with a Capital Assistance

41 SIGTARP QUARTERLY REPORT, supra note 27, at 111. The report lists the following core principles in the Treasury's White Paper: (1) seeking to dispose of its ownership interest as soon as practicable, (2) reserving the right to set upfront constraints to protect taxpayers, promote financial stability, and encourage growth, (3) protecting the taxpayer's investment by managing its ownership stake in a hands-off, commercial manner, and (4) voting on core governance issues, including the selection of a company's board of directors and major corporate events or transactions. Id.

42 Id. at 107.

43 Kate Linebaugh, Five Chrysler Directors Are Named, WALl ST. J., July 6, 2009, at B2. Since control is by its very nature an exclusive concept, it would be a difficult argument to say that the government is a controlling shareholder of Chrysler with Fiat and the United Auto Workers Health Care Trust holding such large stakes.

44 SIGTARP QUARTERLY REPORT, supra note 27, at 110.

45 Id. at 112.

$46 \quad$ Id. at 32.

47 Id. at 36

48 Id.

49 Press Release, U.S. Dep't of the Treasury, U.S. Treasury Releases Terms of Capital Assistance Program (Feb. 25, 2009), http://www.ustreas.gov/press/releases/tg40.htm. 
Program (CAP), which would involve the Treasury taking preferred shares convertible into common equity rather than the type of preferred shares used under CPP. CAP was instituted to support the nineteen largest financial institutions taking TARP money by serving as a backstop source of liquidity for those banks after they undergo a stress test designed to determine their long-term liquidity needs. ${ }^{50}$ To date, no institutions have taken capital under the CAP program. One of the requirements of the CAP program is that participating banks give the government convertible preferred shares that have the option of conversion into voting common equity. ${ }^{51}$ The CPP preferred shares carried a $9 \%$ dividend, and would be convertible at the issuing bank's option subject to regulatory approval. Secretary Geithner would also permit banks with preferred shares issued under the CPP to exchange them for CAP convertible preferred shares, and renamed TARP the "Financial Stability Program." 52

On Friday, February 27, 2009, Citigroup and the Treasury reached an accord whereby some of the Treasury's preferred shares in Citi were converted into common equity. ${ }^{53}$ Immediately the price of shares in Citi fell $39 \%$ to reflect the dilution of other common equityholders, and share prices in other banks fell in anticipation of similar conversions at other banks. ${ }^{54}$ This allowed Citi to avoid dividends required under those preferred shares. ${ }^{55}$ The Treasury also announced that other banks that wish to convert their preferred shares will be able to do so at a $10 \%$

50 SIGTARP QUARTERLY REPORT, supra note 27, at 52.

51 Id. at 53.

52 In many ways Secretary Geithner's plan to stabilize banks through issuance of preferred stock convertible into common equity can be traced back to a proposal by the investment bank Friedman Billings Ramsey (FBR) advocating the practice in November 2008. Paul ]. Miller, JR. ET Al., U.S. Financial System Still NeEdS at least \$1.0 Trillion to \$1.2 TRILLION, 1 (2008), available

at http://online.wsj.com/public/resources/media/Financial_Strategy-20081119.pdf. FBR advocated that "if the government would convert TARP capital issuances into pure, tangible common capital (akin to the $\$ 23$ billion class $\mathrm{C}$ investment in $\mathrm{AIG}$ ), it would go a long way toward encouraging subsequent private investment." Id. That analysis also led the march to focus on tangible common equity ("TCE") rather than tier 1 capital as the true indicator of bank financial health. Both are used to examine a bank's health, since the ratio of equity to assets (loans outstanding) of a bank compares the residual interest of common stockholders to the pool of loans in which they have an interest. If either ratio is too low, it means the bank is overleveraged. The Treasury's TARP preferred shares were included in the tier 1 capital ratio, but not the TCE ratio. At the time, FBR urged that TCE at the largest eight financial institutions was $3.4 \%$ of assets, implying $29 \mathrm{x}$ leverage, and that $\$ 1$ trillion in new common equity would be necessary to bring TCE back into normal alignment. Id. at 2 . FBR urged that tier 1 capital, which included TARP preferred stock, was not a good measure of leverage because the preferred stock had a liquidation preference. Id. at 1, 9. FBR also argued that injections of capital connected to preferred stock was something that banks would not use to lend, because that lending would put pressure on its TCE ratio (because preferred shares do not help the TCE ratio, but additional lending would make it look more leveraged). Id. at 9. The Treasury adopted essentially the same justification for the conversion in its statement announcing its conversion of Citigroup shares.

53 David Enrich \& Deborah Solomon, Citi, U.S. Reach Accord on a Third Bailout, WaLl ST. J., Feb. 28, 2009, at B1.

54 Id.

55 Id. 
discount to the February 9, 2009 prevailing stock price. ${ }^{56}$ Twenty billion dollars worth of the Treasury's Citigroup preferred shares were not included in the deal. ${ }^{57}$ When the Treasury Department exchanged its nonvoting preferred shares for voting common equity in Citigroup on June 9, 2009, it executed an Exchange Agreement to govern the transaction. ${ }^{58}$ The opening clauses of that agreement evidence the government's lack of interest in maximizing the value of its investment with an explicit statement of intent that its investment is motivated in part by its desire to stabilize the financial system generally. ${ }^{59}$

Citigroup has agreed to restrictions on its lobbying activities during the term that the government continues to own an interest in it. ${ }^{60}$ Pursuant to its Exchange Agreement with the federal government, Citigroup also remains bound by the Employ American Workers Act.61 Citigroup also remains bound by the Home Affordable Modification Program by the terms of its Exchange Agreement. 62

Under the terms of the Exchange Agreement, the government agrees to begin to sell off its interest in Citigroup by June of 2019 at a rate of $20 \%$ of its holdings yearly. ${ }^{63}$ This may permit it to remain a control shareholder for longer than that ten-year period in light of the large size of its current

\footnotetext{
56 Id.

57 Id.

58 Exchange Agreement Between Citigroup Inc. and United States Department of the $\begin{array}{llll}\text { Treasury, } & \text { June } & 9009,\end{array}$ http://www.sec.gov/Archives/edgar/data/831001/000119312509128765/dex103.htm [hereinafter Exchange Agreement].

59 Id. at 2 . This desire is clear by the Treasury's very act of converting its shares when the conversion makes no economic sense for the Treasury as a shareholder. One reason for the conversion then is that it will artificially increase the bank's common equity, which will give it a good TCE number when the Treasury begins its promised stress testing regime for unhealthy banks. The Federal Reserve has indicated that it will focus on TCE in performing stress tests on banks, in contrast to its previous focus on tier 1 capital. David Enrich \& Monica Langley, U.S. Eyes Large Stake in Citi, WALL ST. J., Feb. 23, 2009, at A2. This is, however, an entirely artificial construct. TCE serves as a good proxy for a bank's health when it reflects the market's interest in becoming the residual beneficiary of fees from the bank's loan portfolio, but here it merely reflects the federal government's willingness to bail out a bank without concern for future price appreciation in its shares. The distinction is entirely arbitrary when the holder in either case is more concerned with other objectives than maximizing the value of its shares. This also presumes that the market is as obsessed with TCE as the Treasury and FBR suggest. In essence, the Treasury is completely rewriting the rulebook with its new stress testing regime. This means it can alter the ratios it emphasizes, or create an entirely new one, drawing the market's focus to the new metric. One way to alleviate the consequences of holding common equity, while helping the banks' TCE number at the same time, would be the frozen options proposal explored in Section VII.B of this Article. The Treasury, the Federal Reserve, and the FDIC could make changes to the definition of TCE in the regulations and in the new stress testing regime to highlight those options as a significant element of common equity in that calculation.

60 Exchange Agreement, supra note 58, at 47.

61 Id. at 51.

62 Id.

63 See id. at 52; Press Release, Citigroup, Citi Announces Public Share Exchange Launch, Finalizes Definitive Agreement with U.S. Government (June 10, 2009), http://www.citibank.com/citi/press/2009/090610a.htm.
} 
$34 \%$ holdings-potentially sixteen to eighteen years depending on the amount of other outstanding shares in Citigroup at that time.

The Treasury retains nearly all of its voting rights under the Exchange Agreement. That agreement initially states that the Treasury will vote its shares in proportion to all other shareholders' votes, but exempts "Designated Matters" from that policy. ${ }^{64}$ Those Designated Matters include nearly all matters on which a shareholder might be interested in voting, including the election and removal of directors, the approval of any business combinations, the approval of a sale of substantially all assets of the Company, approval of a dissolution of the company, approval of new securities, and approval of amendments to the charter or bylaws. 65 The exchange of securities under the Exchange Agreement was subject to shareholder approval, and yet the government's interim securities prior to the approval were so coercive as to effectively guarantee that the Exchange Agreement would be approved by the shareholders. ${ }^{66}$

At a total of $\$ 50$ billion, next to AIG, Citigroup is the second largest recipient of TARP money. And unlike AIG, where the government has an $80 \%$ stake, the government has a sub-majority control block of $34 \%$ in Citigroup. As such, Citigroup will become the most useful real world example for the theoretical and legal analysis presented in this Article. Particularly, the next Part will conduct extensive analysis of the level of control that the federal government has exercised over Citigroup.

\section{The Federal Government as Control Shareholder}

Control is an elusive concept, but it forms an important part of corporate and securities law. It triggers fiduciary duties for control shareholders under state corporate law, as well as a number of applications under the federal securities laws. Some provisions enhance the burden or liability facing controlling shareholders or persons, while others will specifically prohibit actions that create certain control relationships. ${ }^{67}$ Consequences of being deemed in control of a company under the Securities Act of 1933 (the "33 Act" or the "Securities Act") and the Exchange Act, include limits on the controlling person's ability to sell securities in the controlled company unless the securities have been registered and the sale follows various required methods. ${ }^{68}$ Rule 405 of the Securities Act forms the basis for the Securities Act's nebulous definition of shareholder control as "the possession, direct or indirect, of the power to

\footnotetext{
64 Exchange Agreement, supra note 58, at 53.

65 Id.

66 SIGTARP QUARTERLY REPORT, supra note 27, at 68.

67 A.A. Sommer, Jr., Who's "in Control"? -S.E.C., 21 Bus. LAW. 559 (1966).

68 Securities Act of 1933, 15 U.S.C. $\S \S 77 a-77$ aa (2006) [hereinafter "Securities Act"]; Securities Exchange Act of 1934, 15 U.S.C. $\S \S 78 a-7800$ (2006) [hereinafter "Exchange Act"].
} 
direct or cause the direction of the management and policies of a person, whether through the ownership of voting securities, by contract, or otherwise." 69

One of the more costly results of being deemed a control person under the securities laws is exposure to joint and several liability with offending issuers for violations of the securities laws. ${ }^{70}$ Section 15 of the Securities Act mandates joint and several liability for control persons of issuers liable under section 11 and section 12, and section 20(a) of the Exchange Act mandates joint and several liability for control persons of issuers held liable under the Exchange Act, including Rule 10b-5. This is a stark departure from the individual liability protections of the corporate form.

In some areas, the securities laws take a direct approach and prescribe a certain percentage of ownership as constituting control, such as with the presumption in the Investment Company Act of 1940 that a $25 \%$ ownership position in a company constitutes control. ${ }^{71}$ Some of the provisions of the securities laws also take a bright-line approach to regulation of transactions that are based on concerns about controlling shareholders. The proxy rules require filing a Schedule 13D upon taking ownership in $10 \%$ of the voting securities of an issuer. ${ }^{72}$ Section 16 insider trading liability also accrues for $10 \%$ shareholders. ${ }^{73}$

Through Rule 405 under the Exchange Act the SEC has further offered that " $[\mathrm{t}]$ he term control (including the terms controlling, controlled by, and under common control with) means the possession, direct or indirect, of the power to direct or cause the direction of the management and policies of a person, whether through the ownership of voting securities, by contract, or otherwise." 74

However, for the most part the Securities Act and the Exchange Act of 1934 do not provide an explicit definition of just what circumstances lead to control. This has led to much uncertainty and a variety of case law, staff interpretations, and no-action letters exploring the factors that the SEC will use in determining control under those two statutes.

Adolph Berle and Gardiner Means, the original students of the separation of ownership and control, state:

[C]ontrol lies in the hands of the individual or group who have the actual power to select the board of directors (or its majority).... Occasionally a measure of control is exercised not through the selection of directors, but through dictation to the management, as where a bank determines the

\footnotetext{
6917 C.F.R. $\$ 230.405$ (2009).

70 Sommer, supra note 67 , at $560-61$.

71 Investment Company Act of 1940, 15 U.S.C. $\$ 80 \mathrm{a}-2(\mathrm{a})(9)(2006)$.

72 Rule 13d-1, 73 Fed. Reg. 60,050 (Oct. 9, 2008) (to be codified at 17 C.F.R. pts. 230, 239, 240, 249), available at http://www.law.uc.edu/CCL/34ActRls/rule13d-1.html.

73 Exchange Act $\$ 16,15$ U.S.C. $\$ 78 p(2006)$.

74 SEC Rule 405, 73 Fed. Reg. 58,321 (Oct. 6, 2008).
} 
policy of a corporation seriously indebted to it. In most cases, however, if one can determine who does actually have the power to select the directors, one has located the group of individuals who for practical purposes may be regarded as the "control." 75

Thus Berle and Means also recognize that control, though occasionally an issue of contractual rights, is typically more a question of shareholder power.

Former SEC Commissioner A.A. Sommer, in a groundbreaking article on the topic, discusses a question that is relevant to the central thesis of this Article: "How little stock may a person own or have the power to vote and still be considered a controlling person? This depends upon many circumstances. Principal among these are the distribution of the other shares and the other relationships the shareholder has with the corporation and with other shareholders." 76 Sommer goes on to note that "[o]bviously, the more widely dispersed voting stock is generally, the amount necessary to control is smaller."77

A substantial line of authority supports the proposition that either the power to control or actual exercise of control is sufficient. In re Walston and Co., an SEC opinion, holds that the power to control could be evidenced by a creditor's right to $90 \%$ of profits, status as the source of most of Walston's business, and option to acquire stock. ${ }^{78}$ This was despite the fact that the creditor did not participate in the actual management of the business and held no actual stock. ${ }^{79}$ In effect, the power to control is sufficient to make one a controlling person, despite the fact that the power is never actually exercised.

This is analogous to the government's position with respect to many TARP banks. The U.S. government is a substantial creditor of the companies in addition to owning positions in them, ${ }^{80}$ and also holds the ability to substantially affect the bank's underlying business through its discretion in setting capital requirements and limiting bank operations. Under this view, the fact that the Treasury or the Federal Reserve did not engage in active management of TARP banks, and the fact that the Treasury's ownership in most TARP participants is non-voting, would be irrelevant to the government's power to control the banks.

SEC v. Franklin Atlas Corp. ${ }^{81}$ also supports the notion that percentage of stock ownership is not, alone, determinative. In that case, a manager

75 Adolph A. Berle \& Gardiner C. MEANS, The Modern Corporation and Private Property 66-67 (Transaction Publishers 1991) (1932).

76 Sommer, supra note 67 , at 568 .

77 Id. at 569.

78 Exchange Act Release No. 2603, 7 SEC Docket 937 (Aug. 8, 1940).

79 Sommer, supra note 67, at 564 (citing Exchange Act Release No. 2603, supra note 78).

80 See supra Part II (discussing TARP's background).

81 154 F. Supp. 395 (S.D.N.Y. 1957). 
with the ability to control an enterprise was determined to be a control person, even though he actually owned no stock and the company had a different controlling shareholder who owned a majority of the stock. This does not mean that shareholding is irrelevant to the determination; to the contrary, it is generally the most frequently utilized measure.

For the purposes of state corporation law, shareholders deemed to be in control of the corporation owe fiduciary duties of care and loyalty to minority shareholders. ${ }^{82}$ In Delaware, "a shareholder owes a fiduciary duty only if it owns a majority interest in or exercises control over the business affairs of the corporation." ${ }^{83}$ Rather than using a bright-line test of control, the Delaware courts will examine the factors surrounding a shareholder's relationship with the board to determine whether that shareholder is exercising actual control. In re Cysive, a 2003 Delaware Court of Chancery case, strongly supports a finding that the Treasury is a control shareholder in Citigroup after conversion of its preferred stock into nearly $36 \%$ of Citigroup's common equity. ${ }^{84}$ Determinations of control for other TARP participants would be case dependent, but the strong contractual rights the Treasury secured under the initial round of TARP would also support an inference of control. The government's ownership positions in many other TARP companies are smaller than that in Citigroup, and some of them are held in the form of non-voting preferred stock. And yet the government's exercise of power over those firms, in addition to the contractual rights it has under TARP, is revealing. ${ }^{85}$

As one particular example of the government's exercise of power, consider the wide authority that the Treasury Department has placed under the auspices of the Treasury Department Special Master for Compensation (or "Pay Czar"). A discussion of how TARP morphs corporate law would be incomplete without mentioning the executive compensation restrictions included in TARP regulations that are interpreted by the Pay Czar. Section 111 of the EESA was amended by the American Recovery and Reinvestment Act to provide the Treasury with some final guidance for the initial executive compensation provisions

82 See generally Roberta S. Karmel, Should a Duty to the Corporation Be Imposed on Institutional Shareholders?, 60 Bus. LAW. 1, 2 (2004).

83 Ivanhoe Partners v. Newmont Mining Corp., 535 A.2d 1334, 1344 (Del Ch. 1987).

84 In In re Cysive, a person holding $35 \%$, and an option to purchase another $0.5 \%$ to $1.0 \%$, of the stock was deemed to be a controller because he was also Chairman and Chief Executive Officer, and his brother and brother-in-law, who were both employed by the company, held another $0.5 \%$ of the stock. In re Cysive, Inc. S'holders Litig., 836 A.2d 531, 535, 552 (Del. Ch. 2003). By contrast, the Delaware Court of Chancery has also held that a $46 \%$ stockholder was not a controlling stockholder where the $46 \%$ stockholder was limited to electing two members of the board for a period beyond the merger at issue in the litigation and was subject to certain restrictions on the purchase of additional shares. In re W. Nat'l Corp. S'holders Litig., No. 15927 2000 WL 710192, at *25-26 (Del. Ch. May 22, 2000).

85 For example, nearly all TARP recipients must vet their compensation packages through the TARP Special Master for Compensation at the Treasury Department. 
included in that bill.86 The Treasury's interim final rule applies the executive compensation rules to covered officers of companies based on the amount of TARP funding received. ${ }^{87}$

There are a number of restrictions that will apply to these covered employees. First, the only bonuses they are permitted to receive must come in the form of restricted stock, and must not exceed one-third of the executive's total compensation. ${ }^{88}$ There are also restrictions requiring that the TARP companies exercise any clawback rights they may have, disclose efforts to minimize excessive risk, limit golden parachute payments, and disclose any perqs that exceed $\$ 25,000.89$ The Treasury Department also created a Pay Czar position to issue advisory opinions with respect to these rules, as well as to review compensation for firms receiving exceptional assistance. ${ }^{90}$ As the interpreter of the executive compensation restrictions included in the EESA and the stimulus bills, and as the only entity able to give TARP recipients an exemption from coverage, the Treasury gains significant leverage over high-ranking executives who work for TARP recipients, over whose personal compensation the Treasury has become the final arbiter.

Thus we see that as defined under both corporate and securities law, considering the position and powers of a shareholder is one useful method to determine the presence of control. It is not, however, the only method. The actual exercise of authority is also useful.

The Treasury and the Federal Reserve have exercised considerable authority thus far. A prime example of that exercise is revealed by the government's ongoing relationship with Citigroup. At one meeting, the federal government pressured Citigroup to find six new independent board directors acceptable to the U.S. government. ${ }^{91}$

In using its control over Citigroup to cause it to end dividend payments to preferred stockholders, the Treasury implicitly pressured the other preferred shareholders to convert their shares into common equity. ${ }^{92}$ Those preferred shareholders who exercised the conversion were able to do so at a preferential stock price of $\$ 3.50$ per share. ${ }^{93}$ The government's regulatory oversight, and its oversight as a holder of a controlling stake in Citigroup, is coordinated through four agencies: the

86 SIGTARP QUARTERLY REPORT, supra note 27, at 118.

87 Id. at 121 . Covered employees are determined based on TARP money taken.

88 Id. For more on the use of restricted stock to minimize risk, see Sanjai Bhagat \& Roberta Romano, Reforming Executive Compensation: Focusing and Committing to the Long-Term, 26 YALE J. ON REG. 359 (2009).

89 SIGTARP QUARTERLY REPORT, supra note 27 , at 121.

90 Id. at 122.

91 Joann S. Lublin, Citi Board Revamp Faces Hurdles, WALL ST. J., Feb. 28, 2009, at B3.

92 Peter Eavis, Paying the Price To Rebuild Citi, WALl ST. J., Feb. 28, 2009, at B12.

93 Id. 
Treasury, the Office of the Comptroller of the Currency, the Federal Reserve, and the FDIC. ${ }^{94}$

In an attempt to minimize fears of nationalization, Chairman Bernanke indicated that the federal government would avoid taking majority stakes in banks whenever possible. ${ }^{95}$ But this ignores analysis of real control. The Treasury Department has recognized that minority interests in companies can effectuate control in its own regulations. In the rules promulgated to implement the Foreign Investment and National Security Act of 2007, whereby the Committee on Foreign Investment in the United States (CFIUS) reviews foreign governments that invest in U.S. companies, the Treasury takes an expansive view of control. ${ }^{96}$ It indicates that a $10 \%$ interest is a strong presumption of control, but is willing to consider smaller stakes as controlling. Under the CFIUS definition, the Treasury's CAP Citigroup shares are firmly defined as a controlling interest in those securities at $36 \%$ interest. They would also be considered a controlling interest under the SEC's definition, and meet the definition of control shareholder under state corporate law. ${ }^{97}$

The Treasury Department has converted its preferred shares in Citigroup into common equity, giving it a position of up to $36 \%$ of Citi's outstanding voting equity. This means that as defined under Delaware corporate law, the securities laws, and even the CFIUS process for reviewing foreign investments in U.S. companies, the U.S. Treasury is a control shareholder in Citigroup. Further, the remaining unconverted preferred shares in other banks issued to the Treasuryby TARP

94 Monica Langley \& David Enrich, Citigroup Chafes Under U.S. Overseers, WALL ST. I., Feb. 25,2009 , at $A 1$. at $\mathrm{A} 2$.

95 Sudeep Reddy, Bernanke Eases Bank-Nationalization Fears, WALL ST. J., Feb. 25, 2009,

96 See Regulations Pertaining to Mergers, Acquisitions, and Takeovers by Foreign Persons, 31 C.F.R. pt. 800 (2009). Specifically, "control" is defined as the "power, direct or indirect, whether or not exercised, through the ownership of a majority or a dominant minority of the total outstanding voting interest in an entity, board representation, proxy voting, a special share, contractual arrangements, formal or informal arrangements to act in concert, or other means, to determine, direct, or decide important matters affecting an entity; in particular, but without limitation, to determine, direct, take, reach, or cause decisions regarding the [matters listed in $\S$ 800.204(a)], or any other similarly important matters affecting an entity." See id. $\$$ 800.204(a). Two points should be emphasized concerning this definition. First, it eschews bright lines. Consistent with the existing regulations, control is not defined in terms of a specified percentage of shares or number of board seats. Although shareholding and board seats are relevant to a control analysis, neither factor on its own is necessarily determinative. Instead, all relevant factors are considered together in light of their potential impact on a foreign person's ability "to determine, direct, or decide important matters affecting an entity." Second, echoing the congressional views expressed in the conference report accompanying the original legislation in 1988, the focus of the statute and therefore of these regulations is a control person controlled by or acting on behalf of a foreign government. For example, a transaction involving a foreign person's acquisition of nine percent of the voting shares of a U.S. business in which the foreign person has negotiated rights "to determine, direct, decide, take, reach, or cause decisions regarding" important matters affecting that business would be a covered transaction. $I d$.

97 Cf. In re Cysive, Inc. S'holders Litig., 836 A.2d 531, 535, 551-52 (Del. Ch. 2003). 
participants give the government substantial leverage over corporate policy decisions at those banks.

The Treasury's exercise of its new power over Citigroup has already begun, and some of the ways in which the Treasury's interests and the long-term profitability of the bank may come into conflict have already been revealed. Citigroup has begun to cave to political pressure to engage in corporate policy decisions that, though unprofitable for the bank, are politically useful to its government regulators. It announced a plan to lower mortgage payments by an average $\$ 500$ per month for those homeowners who have recently lost their jobs and are more than sixty days behind on their mortgages. ${ }^{98}$ Borrowers who have lost their jobs may be particularly poor bets for workouts, as they lack stable cash flows to pay even reduced mortgages. Citigroup also expressed support for a congressional plan to allow judges to modify mortgages, legislation it opposed prior to receiving preferential treatment from the Treasury, and which the rest of the banking industry opposed. ${ }^{99}$ The federal government has pressured Citigroup to "sell business lines that don't mesh with the company's core mission." 100 Further, one account suggests that the jumble of conflicting orders and oversight from the agencies overseeing Citigroup and congressional interest has strained Citigroup's ability to operate effectively. ${ }^{101}$

Congressional pressure has often related to issues that represent a miniscule effect on the Treasury's balance sheet or income, particularly executive compensation and perqs, including the use of corporate airplanes. ${ }^{102}$ After taking control of the IndyMac Bank, the FDIC also adopted a policy of modifying mortgages with the aim of "keeping mortgage holders in their homes," which suggests a diminished concern for corporate profitability. ${ }^{103}$

In order to minimize what they see as political misuse of those events to spur public outcry, banks participating in TARP have cancelled employee reward programs and training events that are immaterial compared to their budgets but that management believes otherwise serve a useful function. ${ }^{104}$ Citigroup also explored cancelling its marketing sponsorship of the New York Mets' stadium for the same reason. ${ }^{105}$

\footnotetext{
98 Ruth Simon, Citi To Allow Jobless To Pay Less on Loans, WALL ST. J., Mar. 3, 2009, at A4.

99 Id.

100 See David Enrich, Citi To Sell a Portion of Stake in Redecard, WALL ST. J., Feb. 20, 2009 , at C2.

101 Langley \& Enrich, supra note 94.

102 Id.

103 Sudeep Reddy, Taking the Nationalization Route To Fix the Banks, WALL ST. J., Feb. 24,2009 , at A4.

104 Robin Sidel, Capital Clash: Banks v. Rescue, WALL ST. J., Feb. 10, 2009, at C3.

105 David Enrich, Matthew Futterman \& Damian Paletta, Citi Explores Breaking Mets Deal, Wall ST. J., Feb. 3, 2009, at A1.
} 
Another concern with the Treasury's equity in Citi is that, with the U.S. government as a controlling stakeholder in a bank, other governments will alter their policies toward international branches or divisions of that bank in order to extract diplomatic concessions from the U.S. government. ${ }^{106}$ Another unintended consequence of the Treasury's bailout has been that customers have gravitated to bailed-out institutions, giving those institutions which participated in TARP a competitive advantage over competitors that were ironically safer prior to the bailout. ${ }^{107}$ This dynamic is likely to continue as long as the Treasury holds stakes in banks, particularly in light of the observation that government-owned banks receive regulatory preferences and are more likely to obtain government backing than non-government-owned institutions.

Citigroup is a useful example to consider, but the government's exercise of control and its conflicts spread out over all TARP recipients. The potential for conflicts in the Treasury's financial company TARP holdings in banks is vast. For one thing, wealth management is a cornerstone business for investment banks. In large part, this translates to tax planning and helping clients to legally avoid taxes on their assets. Investment banks also finance mergers and acquisitions ("M\&A") activity that can result in downsizing and plant closures in targeted firms. This could result in political pressure to reduce $M \& A$ financing and deal advisory relationships by labor and regional constituencies. Auto, consumer, and home loans are another major business for investment and commercial banks. All of these groups can seek to pressure political overseers at TARP banks to subsidize their lending. TARP banks might be pressured to subsidize lending through lower interest rates to certain geographic areas or certain income groups, resulting in a loan portfolio with risk not matching its expected future cash flows. TARP banks might be pressured to subsidize lending to state and local governments, or close operations overseas. TARP banks might be pressured by overseas governments to extract diplomatic concessions from the U.S. government. This dynamic might also spill over into the automotive TARP recipients, which would permit the government to achieve through its TARP equity powers what it may not be able to achieve through other environmental and labor regulatory powers.

Citigroup stands as the prime example for the government's exercise of control over the institutions that have taken TARP money. It is likely that the lower the percentage ownership the government has in a TARP firm, the lower its control. As such, its potential to control likely drops quickly as one goes beyond the top twenty or thirty TARP banks. This Part has 26,2009 , at C3.

106 David Enrich, Heidi N. Moore \& Joann S. Lublin, Citi Nears Stake Deal, WALL ST. J., Feb.

107 Doug Cameron, MF Global Cites TARP Fallout, WALL ST. J., Feb. 6, 2009, at C3. In the brokerage area, for instance, segregated client funds held by banks participating in TARP rose by $26 \%$ from August 2008 to November 2008, while funds in institutions that did not participate in TARP fell $12 \%$. Id. 
omitted analysis of AIG, in which the government has an $85 \%$ stake, Fannie and Freddie, which the government completely owns, and GM, in which the government is also a majority owner. ${ }^{108}$ But the Citigroup example reveals how equity holdings can give government shareholders particular power, which when combined with regulatory authority can make a shareholder that would otherwise be non-controlling suddenly obtain control.

\section{Shareholder Control Meets Sovereign Immunity}

As explored in more depth in other areas of this Article, controlling shareholders have significant liability to other shareholders under law. This Article notes that the government as a shareholder may have a political interest in pursuing goals that directly harm the interest of other shareholders in the corporation. And yet, one of the novel aspects of the government's holdings under TARP is that it has substantial sovereign immunity from liability as a controlling shareholder.

Generally, the United States is immune from suit unless it waives its sovereign immunity and consents to being sued. ${ }^{109}$ The government's sovereign immunity also extends to its agencies unless Congress has consented to suit. ${ }^{110}$ As a general observation, waiver of the sovereign immunity of the United States "cannot be implied but must be unequivocally expressed." 111 Determining the nature and extent of the government's sovereign immunity for a particular kind of suit is a complicated exercise. First, we begin with a general presumption of immunity. Then we will need to determine if liability fits under one of the waivers to sovereign immunity passed by Congress. Finally, we will need to analyze the application of one of the express limits on liability found in either the EESA or the federal securities laws.

Pursuant to the Tucker Act, 112 the Court of Federal Claims has jurisdiction to render judgment upon any claim against the United States founded upon the Constitution, any act of Congress, any regulation of an executive department, or any express or implied contract with the United States, or for liquidated or unliquidated damages in cases not sounding in

108 Though GM is not publicly traded, at some point the government will slowly sell off its shares, and at that time it is likely to become as cogent an example of government control as the other examples in this Article.

109 See United States v. Mitchell, 463 U.S. 206, 212 (1983) (holding that it is "axiomatic that the United States may not be sued without its consent and that the existence of consent is a prerequisite for jurisdiction").

110 Gilbert v. DaGrossa, 756 F.2d 1455, 1460 n.6 (9th Cir. 1985).

111 United States v. King, 395 U.S. 1, 4 (1969) (quoting United States v. Sherwood, 312 U.S. $584(1941))$.

112 For more on the difficulty in prosecuting Tucker Act claims in other contexts, see Adam Mossoff, Patents as Constitutional Private Property: The Historical Protection of Patents Under the Takings Clause, 87 B.U. L. REV. 689, 711 (2007). 
tort. ${ }^{113}$ The Tucker Act confers no substantive right of recovery, and such a right must be grounded in a contract, a statute, or a regulation. ${ }^{114}$ Further, claims under the Tucker Act are permitted solely for suits seeking an award of monetary damages. 115

A claim for damages under the Tucker Act must originate in another source of federal law that can be interpreted to mandate compensation for which the government is liable; a plaintiff needs to prove that a reasonable reading of the statute would mandate damages. ${ }^{116}$

In order for a plaintiff to prevail on a Tucker Act claim that might exist under the list of claims generally found under state corporate law, the claim would need to be included in one of the enumerated categories listed, and "state corporation law" is not included. The only avenue, if any, which would apply is a violation of the Constitution. Takings Clause litigation is a substantial body of Tucker Act jurisprudence. One theory which may potentially be squeezed under that umbrella would be a novel theory that the diminishment in share value resulting from the government control shareholder's actions constituted a taking under the Constitution.

Takings Clause cases are particularly difficult to win. ${ }^{117}$ In order to establish a regulatory taking under the Fifth Amendment, the Penn Central case uses a fact-based inquiry that considers (1) the economic impact of the action on the claimant, (2) the effects of the governmental action on the reasonable investment-backed expectations of the claimant, and (3) the character of the governmental action. ${ }^{118}$ The first prong would be complicated by the difficulty of measuring the effect of, for example, M\&A deals encouraged by the control shareholder when no independent auction was completed. As such, there would be no economic damage to effectively measure. The second prong may be difficult for any plaintiffs who purchased their investment after TARP began, or with the expectation that the government may bail out the bank or automotive company and take a controlling equity position, as the investment-backed expectations prong requires a showing that the plaintiff acquired an interest "in reliance on a state of affairs that did not include the challenged regulatory regime." 119 The third prong may be difficult for a plaintiff to meet in light of the

\footnotetext{
11328 U.S.C. §1491(a)(1) (2006); see also 32B AM. JUR. 2D Federal Courts $\$ 1997$.

114 See United States v. Connolly, 716 F.2d 882, 885 (Fed. Cir. 1983).

115 United States v. Jones, 131 U.S. 1, 9, 18 (1889) (noting that enactment of the Tucker Act did not expand the powers of the Court of Claims beyond judgments for money).

116 Samish Indian Nation v. United States, 82 Fed. Cl. 54 (2008).

117 Robert Meltz, Takings Law Today: A Primer for the Perplexed, 34 EcoLogY L.Q. 307, 311 (2007).

118 Penn Cent. Transp. Co. v. City of New York, 438 U.S. 104, 124 (1978).

119 Loveladies Harbor, Inc. v. United States, 28 F.3d 1171, 1177 (Fed. Cir. 1994).
} 
government's articulation that its ownership interest and exercise of power is intended to minimize damage to financial markets. ${ }^{120}$

The second avenue to attempt under the Tucker Act is to use an implicit waiver argument. The Supreme Court has held that "[w]hen the United States enters into contract relations, its rights and duties therein are governed generally by the law applicable to contracts between private individuals," 121 and that once the United States waives its immunity and does business with its citizens, it does so effectively as a party never cloaked with immunity. ${ }^{122}$ One could argue that share ownership is merely a form of contractual relations that happens to be governed by an extensive set of mandatory and default rules that constitute the law applicable to those particular "contracts between private individuals." If that reasoning holds, then it would seem that the EESA may constitute the sole limitation on suit against the government's actions in putting pressure on the corporation. Arguing that share ownership is a contractual relation would be unlikely for Delaware corporations, however. The Delaware Court of Chancery has been careful to maintain a clear distinction between contract law and corporate law. ${ }^{123}$

Even if plaintiffs were to seek compensation under the Tucker Act in the Court of Federal Claims, they would not be able to obtain the types of remedies that corporate law plaintiffs typically seek. Injunctions against mergers are one of the more frequent remedies that plaintiffs obtain in the Court of Chancery, and a claim based solely on the Tucker Act would not be open to such a remedy. ${ }^{124}$ One of the reasons that Chancery will likely

120 Pub. L. No. $110-343$, div. A, $\S 2,122$ Stat. 3766 (2008) (to be codified at 12 U.S.C. $\S$ $5201(1))$.

121 Mobil Oil Exploration \& Producing Se., Inc. v. United States, 530 U.S. 604, 607 (2000) (quoting United States v. Winstar Corp, 518 U.S. 839, 895 (1996) (plurality opinion)).

122 Franconia Assocs. v. United States, 536 U.S. 129, 141 (2002) (citing Clearfield Trust Co. v. United States, 318 U.S. 363, 369 (1943) (holding that "[t]he United States does business on business terms")).

123 Compare Gale v. Bershad, No. CIV. A. 15714, 1998 WL 118022, at *5 (Del. Ch. Mar. 4, 1998) (holding that " $[t]$ o allow a fiduciary duty claim to coexist in parallel with an implied contractual claim, would undermine the primacy of contract law over fiduciary law in matters involving the essentially contractual rights and obligations of [the] shareholders"), with Jedwab v. MGM Grand Hotels, Inc., 509 A.2d 584, 594 (Del. Ch. 1986) (holding that "with respect to matters relating to preferences or limitations that distinguish preferred stock from common, the duty of the corporation and its directors is essentially contractual and the scope of the duty is appropriately defined by reference to the specific words evidencing that contract; where however the right asserted is not to a preference as against the common stock but rather a right shared equally with the common, the existence of such right and the scope of the correlative duty may be measured by equitable as well as legal standards").

124 One exception to this general rule is that Congress enacted the Remand Act of 1972, allowing the Court of Federal Claims to grant limited equitable relief. See Gregory C. Sisk, The Tapestry Unravels: Statutory Waivers of Sovereign Immunity and Money Claims Against the United States, 71 GEO. WASH. L. REV. 602, 611-12 (2003) ("The court's limited equitable authority, however, is incidental and collateral to a Tucker Act claim for a money judgment."). This changes little, as the plaintiff would still need to make a claim for damages to sustain the complaint, and would be unable to do so in the absence of a court order requiring an auction. 
enjoin mergers or other corporate policy decisions rather than award damages after the fact is that damages in corporate deals (for example, from unfair mergers) are particularly difficult to determine once a deal is complete. ${ }^{125}$ The practical result may be that if any Tucker Act claims were available, plaintiffs may lose for insufficient proof of damages.

A second central waiver of government sovereign immunity for our purposes is the Administrative Procedure Act (APA), which permits suits against officers of the federal government. ${ }^{126}$ This Act is limited in that (1) claims for relief in the nature of "money damages" are excluded from the APA under section 702; (2) final agency action is reviewable in court under the APA only when there is "no other adequate remedy" in a court; and (3) relief is precluded under the APA "if any other statute that grants consent to suit expressly or impliedly forbids the relief which is sought." 127 As will be discussed later in this Part, the EESA explicitly limits substantive application of the APA to TARP purchases.

The other blanket waiver of sovereign immunity that must be addressed in considering the federal government's immunity as a TARP shareholder is the Federal Tort Claims Act. ${ }^{128}$ This Act is distinct from the Tucker Act and is subject to a unique line of precedents. In addition, jurisdiction to hear tort claims against the federal government is exclusively granted to the United States District Courts under the Federal Tort Claims Act and thus cannot be considered under the Tucker Act. ${ }^{129}$ For the purposes explored in this Article, there are no viable federal common law avenues for a suit. In particular, there is little support for the existence of a fiduciary duty under the federal common law. ${ }^{130}$

125 For instance, if a controlling shareholder were to force a merger through a process that was determined to be unfair to the company's other shareholders, and an auction or shopping period was the only way to determine what the shareholders would have gotten in a fair process, no method for determining damages would be readily available once the transaction was consummated. Conducting a hypothetical auction would not work, since no party would have "skin in the game." One method available would be to conduct an outside appraisal to determine the inherent value of the business and its value to other potential bidders. As that would require access to information from parties not privy to a suit, the lack of incentive to participate would limit appraisal as a method to calculate the value shareholders would get from an alternative bidder in a board process that was not subject to control by an interested shareholder.

1265 U.S.C. $\S 702$ (2006) ("An action in a court of the United States... stating a claim that an agency or an officer or employee thereof acted or failed to act in an official capacity or under color of legal authority shall not be dismissed nor relief therein be denied on the ground that it is against the United States or that the United States is an indispensable party. The United States may be named as a defendant in any such action, and a judgment or decree may be entered against the United States.").

127 Id. $\S \S 702,704$.

12828 U.S.C. $\S \S 1346(\mathrm{~b}), 2671-2680(2006)$.

129 McCauley v. United States, 38 Fed. Cl. 250, 264 (1997).

130 See Roberta S. Karmel, The Securities and Exchange Commission Goes Abroad To Regulate Corporate Governance, 33 STETSON L. REv. 849, 851 (2004) ("In Santa Fe Industries, Inc. v. Green, the United States Supreme Court seized an opportunity to quash the development of a judge-made federal law of corporate fiduciary duty under Section 10(b) of the Exchange Act: The Supreme Court reversed and held that Section 10 (b) cases require 'deception, misrepresentation, 
A reading of the EESA, which created and authorized TARP, reveals an even stronger protection from liability. The Treasury Secretary's decisions pursuant to the EESA are generally subject to Chapter 7 of Title 5 of the U.S. Code, including review for decisions that are "arbitrary, capricious, or an abuse of discretion, or not in accordance with the law." 131 It nevertheless also provides that "no action or claims may be brought against the Secretary by any person that divests its assets with respect to its participation in a program under this Act ... other than as expressly provided in a written contract with the Secretary." 132 It further provides that "[n]o injunction or other form of equitable relief shall be issued against the Secretary for actions pursuant to sections 101,102,106, and 109 , other than to remedy a violation of the Constitution." 133 Those sections give the Treasury the authority to purchase troubled assets. EESA vests in the Secretary of the Treasury the sole authority to exercise the rights in connection with assets acquired under the TARP program. ${ }^{134}$ Troubled assets under the EESA are defined as "any other financial instrument that the Secretary, after consultation with the Chairman of the Board of Governors of the Federal Reserve System, determines the purchase of which is necessary to promote financial market stability." 135 There is also no sunset provision with respect to the Treasury's ability to hold troubled assets. ${ }^{136}$

Abuse of discretion, the threshold in APA cases, would likely preclude fiduciary duty review, whether by other bank shareholders or by taxpayers. According to Cass Sunstein and Thomas Miles, the government wins somewhere between $55 \%$ and $65 \%$ of the time under the arbitrary and capricious review standard. ${ }^{137}$ And yet, since arbitrary and capricious review is principally an issue of equitable relief, the injunction exclusion renders it mostly ineffective for the purposes of challenging the Treasury's actions as a shareholder in banks. ${ }^{138}$ Further, review of financial regulators' decisions on how to provide guaranty assistance to banks is likely to obtain wide latitude under the arbitrary and capricious standard,

or nondisclosure.' In so doing, the Court rejected the notion that the securities laws 'federalize the substantial portion of the law of corporations that deals with transactions in securities, particularly where established state policies of corporate regulation would be overridden.'” (citing Santa Fe Indus. v. Green, 430 U.S. 462, 476 (1977))).

131 Emergency Economic Stabilization Act of 2008, Pub. L. No. 110-343, § 119(a)(1)

(2008) (to be codified at 12 U.S.C. $\$ 5229(\mathrm{a})(1)$ ).

132 Id. $\S 119(3)$ (to be codified at 12 U.S.C. $\$ 5229(3)$ ).

$133 I d . \S 119(\mathrm{a})(2)(\mathrm{A})$ (to be codified at 12 U.S.C. $\$ 5229(\mathrm{a})(2)(\mathrm{A}))$.

$134 I d . \S 106(\mathrm{a})$ (to be codified at 12 U.S.C. $\$ 5216(\mathrm{a})$ ).

135 Id. $\S 3(9)(\mathrm{B})$ (to be codified at 12 U.S.C. $\S 5202(9)(\mathrm{B})$ ).

136 See id. $\$ 106(\mathrm{e})$ (to be codified at 12 U.S.C. $\$ 5216(\mathrm{e})$ ).

137 See Steven M. Davidoff \& David Zaring, Regulation by Deal: The Government's Response to the Financial Crisis, 61 ADMIN. L. REv. 463, 520 (2009) (citing Thomas J. Miles \& Cass R. Sunstein, The Real World of Arbitrariness Review, 75 U. CHI. L. REv. 761, 777 (2009)).

138 Id. 
particularly where the decision goes to the heart of the stability of the nation's banking system. 139

The EESA also does not consider application of section 3(c) of the Exchange Act, ${ }^{140}$ which exempts the federal government from coverage by the Exchange Act. As part of its belt-and-suspenders approach to protecting the Treasury Secretary from liability, it also exempts decisions concerning the disposition and management of TARP assets from injunctive relief, 141 even if plaintiffs are able to meet the arbitrary and capricious threshold.

There may be one useful distinction worth drawing on the application of the EESA. It may be that the liability waivers of the EESA would apply to government decisions on how to spend TARP funds, but would not extend to cover the act of pressuring corporations to institute policy changes as a result of the government's ownership in TARP recipients. The legislative history of the EESA is necessarily limited, owing to the rapid timeframe in which it was passed, but some sources indicate that Congress never intended for TARP to be used to openly purchase shares in companies, much less to use that share ownership to give it power over corporate policy decisions at the board level. ${ }^{142}$ As such, that argument, though useful in evading the exemption language of the EESA, would still be no help with trying to find a cause of action under the Tucker Act.

Though the EESA mentions the APA, it does not specifically address the ' 33 Act or the ' 34 Act. The federal government's liability under the federal securities laws is unclear. There is an express rejection of liability for the federal government in the ' 34 Act. ${ }^{143}$ Thus the federal government's immunity from the ' 34 Act is secure under the belt-and-suspenders protection of both the EESA and the ' 34 Act. The ' 33 Act would require a more involved discussion. The ' 33 Act has no such express opt-out as is found in the " 34 Act. Quite the opposite, "person" for the purposes of the '33 Act is specifically defined to include "an individual, a corporation, a partnership, an association, a joint-stock company, a trust, any unincorporated organization, or a government or political subdivision thereof." 144 Since "person" is a reference included throughout the '33 Act to regulate conduct by participants in the securities markets and expose them

139 See, e.g., Huntington Towers, Ltd. v. Franklin Nat'l Bank, 559 F.2d 863 (2d Cir. 1977).

140 See infra note 322. $5229(\mathrm{a})(2)(\mathrm{A}))$.

141 Pub. L. No. 110-343, div. A, tit. I, § 119(a)(2)(A) (2008) (to be codified at 12 U.S.C. §

142 See Nouriel Roubini, Is Purchasing $\$ 700$ Billion of Toxic Assets the Best Way To Recapitalize the Financial System? No! It Is Rather a Disgrace and Rip-Off Benefitting Only the Shareholders and Unsecured Creditors of Banks, RouBINI GLOBAL ECON., Sept. 28, 2008, http://www.roubini.com/roubini-monitor/253783/; see also Paul Krugman, Doing the Right Thing?, N.Y. TimES, Oct. 9, 2008, http://krugman.blogs.nytimes.com/2008/10/09/doing-the-rightthing/.

143 See Exchange Act § 3(c), 15 U.S.C. § 78c(c) (2006).

144 Securities Act $\S 2 a-2,15$ U.S.C. $\$ 77 b(a)(2)(2006)$ 
to liability for inappropriate conduct, ${ }^{145}$ it would not seem that the intent behind the ' 33 Act was to shield the government from liability.

The inclusion of governments in the meaning of "person" in the ' 33 Act may be an avenue for liability under the ' 33 Act. This would be limited, however, to section 12 violations. It would not include Rule 10b-5 violations, nor would it encompass putting pressure on boards in ways that harm the value of the enterprise unless such action was also accompanied by a material omission from a registration statement or prospectus or failure to deliver a prospectus.

The '34 Act states:

No provision of this title shall apply to, or be deemed to include, any executive department or independent establishment of the United States, or any lending agency which is wholly owned, directly or indirectly, by the United States, or any officer, agent, or employee of any such department, establishment, or agency, acting in the course of his official duty as such, unless such provision makes specific reference to such department, establishment, or agency. ${ }^{146}$

This provision is also relevant to the determination of control shareholder status. If the Treasury, Fed, or an established trust is not considered a control shareholder for the purposes of the ' 34 Act, then it may not share joint and several liability under the securities laws.

The next issue is whether individuals appointed to the board of directors share any governmental immunity. The Federal Reserve's holdings in AIG, purchased mostly through TARP funds, were placed under the ownership of a trust. There is an open question as to whether the trust is actually independent from the government. 147 The Treasury Secretary has indicated his intent to place common stock held in Citigroup into a similar trust sometime in the future. Thus the analysis of sovereign immunity would need to continue to consider application to the trustees.

If the trust or its trustees are not considered to be agents or officers of the United States, the analysis becomes much more complicated. ${ }^{148}$ The sovereign immunity of the United States from suit without its consent does not extend to its officers or agents, ${ }^{149}$ and an action against an official or agency of the United States is not necessarily a suit against the United

145 See, e.g., id. $\$ 5,15$ U.S.C. $\$ 77 \mathrm{e}$.

146 Exchange Act $\S 3(\mathrm{c}), 15$ U.S.C. $\$ 78 \mathrm{c}(\mathrm{c})(2006)$.

147 See AIG, Where Is the Taxpayer Money Going?: Hearing Before the H. Comm. on Oversight and Government Reform, 111th Cong. (2009) (statement of J.W. Verret) [hereinafter Verret Testimony] available

http://oversight.house.gov/images/stories/documents/20090512175538.pdf.

148 See generally 91 C.J.S. United States $\$ 222(2000)$.

149 Gautreaux v. Romney, 448 F.2d 731 (7th Cir. 1971); Pan Am. Petroleum Corp. v. Pierson, 284 F.2d 649 (10th Cir. 1960). 
States. ${ }^{150}$ Where defendant's conduct is such as to create a personal liability, the fact that the defendant is an officer of the United States does not forbid a court from taking jurisdiction in a suit against him or her. ${ }^{151}$

Generally, "[r]elief sought nominally against an officer is in fact against the sovereign if the decree would operate against the latter." 152 For the most part, a suit is considered one "against the sovereign if the judgment sought would expend itself on the public treasury or domain, or interfere with the public administration, or if the effect of the judgment would be to restrain the government from acting, or compel it to act."153 However, "it is not an easy matter to reconcile all the decisions of the Court in this class of cases." 154 It is unclear whether a suit against the AIG trust would ultimately result in an expenditure by the government. The indemnification provisions of the AIG trust begin with a requirement that AIG indemnify them for any liability that they face as trustees, but the Federal Reserve agrees to indemnify any amounts AIG is unable to provide. ${ }^{155}$ It does seem that a judgment against the AIG trustees would result in restraint on the government's ability to fulfill its purposes, in light of how the AIG Trust Agreement includes various provisions that compel the trustees to meet their fiduciary duty to the Treasury and to consider the effect of their decisions on capital markets more broadly.

To the extent that the government places control of its TARP securities in a separate entity by establishing a trust, as it did with AIG, a shift may occur in the relationship between determining the existence of a control shareholder and the existence of immunity. The more that the AIG trust is determined to be a government actor, the more likely it will be in control of the company. However, to obtain the protection of sovereign immunity, the trust would want to show that it is a government entity.

There are very few limitations on trustee indemnification in the AIG Trust, and trustee fiduciary duty is defined in a vague way such that the Treasury's interpretation on the reach of immunity would likely control.156 Despite a lack of immunity from the laws referenced above, the documents creating the AIG Trust would limit the reach of liability even if sovereign immunity does not cover the AIG trustees. Legislation currently pending

150 Smith v. Am. Asiatic Underwriters, Fed., Inc., U.S.A., 134 F.2d 233 (9th Cir. 1943) (on appeal from the U.S. Court for China); Archbold v. McLaughlin, 181 F. Supp. 175 (D.D.C. 1960).

151 Larson v. Domestic \& Foreign Commerce Corp., 337 U.S. 682 (1949); United States ex rel. Brookfield Constr. Co. v. Stewart, 234 F. Supp. 94 (D.D.C. 1964).

152 Pennhurst State Sch. \& Hosp.v. Halderman, 465 U.S. 89 (1984).

153 Dugan v. Rank, 372 U.S. 609, 620 (1963) (internal citations and quotation marks omitted).

154 Larson, 337 U.S. at 698.

155 See AIG Credit Facility Trust Agreement Dated as of January 16, 2009, Among Federal Reserve Bank of New York, and Jill M. Considine, Chester B. Feldberg and Douglas L. Foshee, as trustees, available

http://www.ny.frb.org/newsevents/news/markets/2009/AIGCFTAgreement.pdf. 156 Id. 
may change the nature of any future trusts set up by the Federal Reserve or Treasury. 157

\section{Implications for Corporate Law Theory}

This Part will examine the kaleidoscope of theories commentators have offered in their efforts either to justify existing structures in corporate and securities law or to urge reform. Those theories will be examined in light of the presence of a controlling government shareholder that enjoys sovereign immunity. This Part will show that of the six central theories used in corporate law, including classic agency and contractarian thought, shareholder primacy, director primacy, the team-production model, and progressive corporate law, none of them supports the presence of the federal government as a control shareholder in a publicly traded company. Even more than that, these theories that serve to illuminate corporate law debates and rarefy the opposing parties tend to break down entirely when considered with the presence of such a shareholder.

\section{A. Agency Theory}

Agency theory is the bedrock of corporate law most frequently cited in its theoretical development, and is the first well-developed building block in the debate. The standard Michael Jensen and William Meckling story of agency costs has been used to explain the relationship between shareholders and the board of directors. Where the providers of capital to an enterprise, the shareholder principals, and the users of that capital, the managerial agents, are both utility maximizers, there is reason to believe that the agents' interests can conflict with their principals' interests. ${ }^{158}$ Then in order to maintain capital flows, manager agents will incur bonding costs to assure principals, and principals will incur monitoring costs to minimize instances of agents' abusing their authority over the principals capital. 159

One complication to this model for government shareholders is that the notions of utility that are being maximized will substantially change. Thus the government shareholders and the other shareholders will have different definitions of utility. Indeed, their utility priorities may be in direct contravention to each other. This will make monitoring and bonding

157 See TARP Recipient Ownership Trust Act of 2009, S. 1723, 111th Cong. (as introduced in Sept. 2009).

158 Michael C. Jensen \& William H. Meckling, Theory of the Firm: Managerial Behavior, Agency Costs and Ownership Structure, 3 J. FIN. ECON. 305, 308 (1976).

159 Id. 
more difficult, as the agents will have to serve two masters rather than just one. 160

And yet, in light of the fact that government equity holdings go hand in hand with government bailouts, the other shareholders will be the beneficiary of the government subsidy. They will, however, be adversely affected by the distorted incentives for risk-taking that the government subsidy will also engender. Balancing these benefits against their costs will substantially alter their monitoring costs. The infrastructure of the securities markets has a difficult time gauging the risk of bankruptcy, with share prices tending to fall dramatically near a bankruptcy event. The share prices of Fannie and Freddie are an acute example. ${ }^{161}$ Shareholders have to gauge the likelihood of the Treasury giving further bailouts, or deciding to take the firm into receivership. This sort of political risk is difficult for them to gauge, as the skills needed to do it are quite distinct from other calculations particular to securities analysis. The risk of bankruptcy, coupled with a corollary risk that the government will fail to bail out a firm sufficiently to protect its equityholders, may be the sort of tail end, black swan event that is currently being explored as prone to bounding the rationality of investors. 162

Jensen and Meckling postulated that agency costs would depend in part "upon the cost of measuring the manager's (agent's) performance and evaluating it, the cost of devising and applying an index for compensating the manager which correlates with the owner's (principal's) welfare, and the cost of devising and enforcing specific behavioral rules or policies." 163 The indeterminate nature of the government's interest and its incongruent relationship to the goals of most other shareholders will drastically increase these agency costs for the entire operation, which will be evidenced by a discount in the value of minority shares in the company.

Jensen and Meckling also postulated that where capital markets are characterized by rational expectations of profit maximization, a firm's debt to equity ratio will be reflective of the agency costs of monitoring that firm's managers. ${ }^{164}$ Governments as shareholders, with their unique

160 When risk and reward are disjoined, incentives for well informed and prudent management of risk are abandoned. In Fannie and Freddie's case, this took the form of improper hedging of interest rate risk. Wallison, supra note 24 , at 4 . The perverse incentives created by this government backing do not only impose costs on the guaranteed firms. They also enhance systemic risk within the financial system, defined as the risk that a failure within one institution can result in failure to linked institutions sufficient to cause large-scale shocks to the economy. See Peter J. Wallison, The Evolution of a Policy Idea: How Restrictions on the Size of the GSEs' Portfolios Became the Central Issue in Reform of Their Regulation 3-6 (Networks Fin. Inst. Working Paper, No. 2006-PB-03, 2006), available at http://www.aei.org/docLib/20060314_SystemicRisk.pdf.

161 Basic Chart for Federal National Mortgage Association, Yahoo! Finance, http://finance.yahoo.com/q/bc?s=FNM\&t=5y\&l=on\&z=m\&q=l\&c= (last visited Feb. 14, 2010). (2007).

162 See Nassim Nichol.as Taleb, The Black SWaN: The ImpaCt of the Highly Improbable

163 Jensen \& Meckling, supra note 158 , at 328.

164 Id. at 355. 
willingness to ignore profit maximization in the value of their shares and bailout the debt of entities in which they hold an interest, seriously threaten this function of outside ownership. The sort of triangular agency that results from government ownership, where the Treasury becomes both control-shareholder principal and agent of the taxpayer, leads to an inefficient use of resources, limiting Coase's rule ${ }^{165}$ that firms will exist only where the cost of market activity exceeds the cost of direct authority.

\section{B. Contractarian Theory}

The contractarian model tries to consider what rules the constituents to the contracts at the nexus of the corporation would adopt if there were a hypothetical bargain. 166 This view, also known as the nexus-of-contracts theory of the corporation, is predicated on the notion that a corporation is a product of bargained agreements. The contractarian model of corporate law supports the use of default rules that shareholders, companies, and constituencies are free to modify by contract. 167

Macey argues that the theory of the firm implies that the law should respect the legal arrangements accepted by those within the firm, as it explicitly calls for regulatory respect for private ordering. ${ }^{168}$ The contractarian model is in many ways a precursor to two subsequent corporate theories, the shareholder primacy model and the director primacy model. Both of those offshoots of the contractarian approach accept shareholder wealth maximization as the determining factor in designing default rules to govern the corporate enterprise, but they differ as to the appropriate allocation of power between shareholders and corporate directors.

With the government being a controlling, immune shareholder, two distinct consequences complicate the description. First, the government can change the rules of the game. Not only that, it can change them after the other parties forming the nexus-of-contracts have made their bargains. Looking at the problem from one direction, globally speaking, though the other parties are free to contract around the default rules, the lack of predictability limits contractual freedom and increases transaction costs. Further, the government's immunity means that, as a participant in the process, it is immune from the rules, default or otherwise.

Therefore, the use of hypothetical bargains becomes an uneasy exercise in examining the government as shareholder, as one of the

\footnotetext{
165 R.H. Coase, The Nature of the Firm, 4 EConomica 386 (1937).

166 Stephen M. Bainbridge, In Defense of the Shareholder Wealth Maximization Norm: A Reply to Professor Green, 50 WASH. \& LEE L. REv. 1423, 1430 (1993).

167 Stephen M. Bainbridge, Community and Statism: A Conservative Contractarian Critique of Progressive Corporate Law Scholarship, 82 CORNELL L. REV. 856, 860 (1997).

168 Jonathan R. Macey, Externalities, Firm-Specific Capital Investments, and the Legal Treatment of Fundamental Corporate Changes, 1989 DUKE L.J. 173, 179.
} 
participants to the bargain enjoys immunity from rules enforcing those bargains, and the immune party also has the ability to change those rules and has discretion in how it enforces them. 169

The contractarian approach also takes the view that the welfare of constituencies like labor or the community can be more efficiently seen to through government welfare regulation, without altering corporate profit maximization goals. ${ }^{170}$ But this view is warped by the presence of a controlling government shareholder. Evidence suggests that the conflicts a government collectively faces when regulating entities they own are resolved in favor of preferential treatment for the government-owned firm. ${ }^{171}$ Thus, welfare regulation is no longer a reliable backstop to any negative externalities from the subset of corporate action that may maximize firm profits but result in a net decrease in social wealth. This regulatory preferential treatment also has the effect of harming the competitive position of non-government-owned firms.

\section{Shareholder Primacy Theory}

Shareholder primacy theory includes two bedrock principles: 1) maximizing long-term shareholder value is the only legitimate objective of the corporation, and 2) designing ways to assist shareholders in exerting control through their powers, including the power to vote at annual meetings, will minimize the agency costs that result from the separation of ownership from control in publicly traded and diffusely held corporations. ${ }^{172}$ It is a direct outgrowth of agency theory.

Absent incentives for proper accountability to shareholders, shareholder primacy scholars urge that management will be tempted to excessively reward their efforts, engage in inappropriate levels of risk, self-

169 To offer an example of how the government changes the rules, consider the response to AIG's payment of prearranged bonuses. See Obama Tries To Stop AIG Bonuses: "How Do They Justify This Outrage?," CNN.COM, Mar. 16, 2009, http://www.cnn.com/2009/POLITICS/03/16/AIG.bonuses/index.html.

170 Bainbridge, supra note 167 , at 877.

171 Fannie and Freddie demonstrate that governments give preferential regulatory treatment to private corporations in which they have effective control. For a substantial period of time, Fannie and Freddie were exempt from securities regulation for their publicly traded equity or debt. It was only in 2002 that they were finally required to register, just prior to the revelation of accounting scandals that ultimately limited their ability to comply with those registration requirements. Peter J. Wallison, The Fannie Freddie Time Bomb, INT'L EcoN., Oct. 1, 2002, at 1. Wallison has also showed that Fannie and Freddie were not effectively policed for antitrust violations owing to their favored status by the executive branch. Peter J. Wallison, Applying the Microsoft Decision to Fannie Mae and Freddie Mac, AM. ENTER. INST., July 25, 2001, http://www.aei.org/paper/14862. A legislative provision was also inserted into Fannie and Freddie's charters to prevent shareholder lawsuits in the event of a government takeover. Holman W. Jenkins, Jr., Rethinking the Fan and Fred Takeover, WALL ST. J., Mar. 4, 2009, at A13. Six weeks before the takeover their chief regulator, James Lockhart, declared them both adequately capitalized.

172 See generally Lucian Bebchuk, The Case for Increasing Shareholder Power, 118 HaRv. L. REV. 833, 850 (2005). 
deal, reject efficient offers for control of the company, and over-invest the resources of the firm. ${ }^{173}$ Shareholder primacy scholars favor creating mechanisms whereby shareholders can exercise control over the corporate policies and the membership of the board of directors can reduce these inefficient temptations. ${ }^{174}$

One of the primary objections to shareholder primacy is the argument that some special interest groups may purchase shares and use their equity powers to vote in directors, or advance policies, that harm the interests of most shareholders in long-term price appreciation. Lucian Bebchuk defends shareholder primacy by observing that changes to corporate policy or elections of new directors will require the approval of a majority of the shareholders. ${ }^{175}$ Bebchuk further argues that since money managers tend to support management and focus on share value, the special interest objection is unwarranted. ${ }^{176}$

In this context, however, the majority vote limitation is no longer present. The government would be a controlling, and particularly powerful, equityholder for many of the companies participating in TARP.177 Even if the government did not own a majority of outstanding shares, it would be able to carry a majority of votes in corporate elections with as low as $20 \%$ ownership stakes, owing to the low voting rates of retail investors and to portfolio diversification requirements for pensions and mutual funds. ${ }^{178}$ Thus if the government's motives in exercising its control rights are suspect, then the majority buffer present in most shareholder voting contests will no longer be present to protect the other shareholders from this problem.

Deciding whether or not to accept an acquisition offer for the corporation is particularly prone to conflicts of interest for corporate managers.179 Acquirers typically are able to offer a premium to the shareholders for the company because they intend to run the company more efficiently. ${ }^{180}$ This may mean replacing the company's management, altering its compensation structure, laying off workers, or closing factories. Under the shareholder primacy norm, if the price offered for the company's shares is more than the underlying value of the company in the market, then a board objective of maximizing shareholder wealth may require

\footnotetext{
173 See id.

174 See, e.g., id.

175 See id. at 883.

176 See id. at 883-84.

177 Enrich \& Langley, supra note 59.

178 See Mark J. RoE, Strong Managers, Weak OWNers: The Political Roots of american CORPORATE FINANCE (1994).

179 See Bebchuk, supra note 172, at 898.

180 See id.; Henry G. Manne, Mergers and the Market for Corporate Control, 73 J. POL. ECoN. 110 (1965).
} 
acceptance of the offer. ${ }^{181}$ Concerned with the prospect of losing their position, however, management may block the offer. ${ }^{182}$ Shareholder primacists therefore argue that management should be required to put the question to a shareholder referendum. ${ }^{183}$

And yet the government has an interest in limiting acquisition activity that mirrors the joint interest of labor and management. Mark Roe has examined how the securities laws evolved as a result of an interest group alliance between labor and management to limit the ability of financial intermediaries to advance interests of shareholder wealth maximization. ${ }^{184}$ Government institutions were the source of these laws and an ally of the interest groups that supported them. If the government responds to interest group pressure even through the buffer of independent agency rulemaking, it would be even easier for it to advance the same objectives through decisions on voting its TARP shares, which are subject to the discretion of the Treasury Secretary.

In addition to the effects of actual acquisitions on shareholder value, the prospect of a takeover has disciplining effects on managerial decisionmaking. ${ }^{185}$ There is substantial evidence that antitakeover protections result in both managerial shirking (failure to properly manage the business) and greater managerial self-dealing. ${ }^{186}$ Thus, if management feels that the Treasury is unlikely to vote in favor of tender offers for the bank, it will be less likely to maximize returns on the bank's shares.

Bebchuk's view therefore does not consider the notion that the shareholder electorate would include a control shareholder with significant immunity not shared by the other shareholders, because that was not the circumstance at the time shareholder primacy developed. ${ }^{187}$

181 See Bebchuk, supra note 172, at 896.

182 See id, at 898.

183 See id. at 896-97.

184 See ROE, supra note 178.

185 See Bebchuk, supra note 172, at 899.

186 See id.

187 For that matter, neither does the team production model. Some other commentators have expressed concern that the federal government as an investor would invest without concern for maximizing the value of its securities in different contexts, including with regard to questions of privatizing social security. See U.S. Gov'T ACCOUNTABILITY OFFICE, SOCIAL SECURITY FINANCING: IMPLICATIONS OF GOVERnMENT STOCK INVESTING FOR THE TRUST Fund, THE FEDERAL BudGET, and THE ECONOMY 3 (1998), available at http://www.gao.gov/archive/1998/a398074.pdf ("The 1994-1996 Advisory Council on Social Security contended that politicians would assert political pressure on the managers of the Social Security Trust Fund to forgo investments based on the potential return and make decisions based on criteria that would 'achieve other economic, social, or political purposes.'"); Benjamin A. Templin, The Public Trust in Private Hands: Social Security and the Politics of Private Investment, 96 KY. L.J. 369, 444 (2008). President Bush's Commission on Social Security noted in its 2001 report that "Government must not invest Social Security funds in the stock market." President's Comm'n To Strengthen Soc. Sec., Strengthening Social Security and Creating PERSONAL WEALTH FOR ALL AMERICANS 13 (2001), available at http://permanent.access.gpo.gov/lps16813/final_report.pdf. 
For the purposes of any TARP company in which the government is a control shareholder, therefore, that analysis would no longer be applicable.

\section{Director Primacy Theory}

Stephen Bainbridge is the leading proponent of the director primacy view, which shares with shareholder primacy the view that the maximization of shareholder wealth is the appropriate duty of directors. It modifies the shareholder primacy view, however, by arguing that resting authority over corporate decisions with a self-sustaining board of directors is the best way to accomplish that objective.

To the extent that director primacy stands opposed to shareholder power, it is a fairly easy fit to find director primacy also opposed to resting control power in a government shareholder's hands. One of the central justifications for the exercise of director discretion is that directors will be held accountable for maximizing shareholder wealth by private litigants under state corporate law. ${ }^{188}$ If the Treasury places government nominees on the boards of banks, those nominees will arguably be protected by government immunity from private suit, as they are serving in an official capacity. Director primacy also seems to argue in favor of director discretion for non-controlled corporations, particularly since controlled corporations are a rare case among large publicly traded companies. Therefore, giving discretion for board decisions of banks controlled by government shareholders does not fit with the efficiency justifications offered for director primacy, as that model was crafted to understand the operation of companies that are not controlled by shareholders (and is in fact used to argue that companies should remain free from control by shareholders).

And yet, at the same time, director primacy becomes confusing in this area. Where the directors for whom director primacy gives support are selected, directly or indirectly, at the behest of the government shareholder, it becomes a difficult task to parse out how the theory fits the present dynamic.

\section{E. Team Production Theory}

Margaret Blair and Lynn Stout's team production model serves to justify the discretion that state corporate law vests with the board of directors. The model explains that the members of the team vital to the economic production of the firm join together and submit to the will of a mediating hierarch, the board of directors, that balances the interests of

188 Stephen M. Bainbridge, Director Primacy: The Means and Ends of Corporate Governance, 97 NW. U. L. REV. 547, 562 (2003). 
the various groups. ${ }^{189}$ It relies on contractarian thinking, but abandons notions of shareholder primacy. Team production is a stakeholder-focused theory that is partly aligned with the progressive corporate law view, and partly with director primacy, but is coterminous with neither. It also stands opposed to the shareholder primacy view. In part the team production theory rests on a conception of the institution of corporate law as a solution for limitations in the ability of corporate constituencies to contract with each other. ${ }^{190}$

When the constituencies opt into their "mediating hierarchy" of the board of directors, 191 federal sovereign immunity from corporate laws complicates this situation in cases where the federal government becomes a control shareholder. Control shareholders would otherwise have fiduciary duties to the corporation just like directors, but since the Treasury is the control shareholder it escapes this duty. This nullifies the status of the mediating hierarch as a creature bound by corporate law, and makes the hierarch the servant of the control shareholder, who itself is not bound by corporate law.

This model is complicated by the fact that the mediating hierarch in the case of a government-controlled company can become captured by the government. This will result in the hierarch favoring certain groups based on those groups' ability to influence the political process regardless of the economic contributions those groups make to the collective enterprise. 192 Blair and Stout observe that horizontal relationships between the various parties contributing to production may be at least as important to productive activities as vertical relationships within the firm. ${ }^{193}$ But in the government-controlled case, that relationship is moved outside the firm and becomes an exercise in obtaining political rather than economic rents. The team production model relies in part on a corollary observation by Raghuram Rajan and Luigi Zingales that members of an economic team suffering from coordination problems can improve their situation by giving control rights to a third party who can control the team's assets and reward the team members. The outsider is rewarded with a share of the team's profits, which then gives the outsider an incentive to choose an

189 See Margaret M. Blair \& Lynn A. Stout, A Team Production Theory of Corporate Law, 85 VA. L. REv. 247, 250-51 (1999).

190 See id. at 250.

191 Id. at 251.

192 Government ownership of banks is most prevalent in poor countries that have poorly defined property rights and underdeveloped financial systems. Greater government ownership of banks within a country is also associated with heavier regulation, greater price controls, and higher black market exchange rates. It is also correlated with lower tax compliance, higher corruption index numbers, and lower productivity. See Rafael La Porta, Florencio Lopez-deSilanes \& Andrei Shleifer, Government Ownership of Banks, 57 J. Fin. 265, 277, 279, 288 (2002).

193 See Blair \& Stout, supra note 189, at 264. 
efficient and productive team. ${ }^{194}$ Indeed, Blair and Stout compare outside oversight mechanisms to internal hierarchs and find that internal hierarchs are more efficient monitors of the firm because those internal decisions are made by individuals with greater knowledge. Internal mediation has significant advantages over external mediation since in conflicts with repeat players the internal player will have more institutional knowledge of the individuals involved. 195

Blair and Stout argue that the fact that public corporate law insulates directors from control by any one group means that they are able to serve the interests of the entire corporate team contributing to the economic growth of the organization. ${ }^{196}$ In the government-controlled case, however, not only is the government able to wrest control from the board, but even worse, its concern for maximizing the value of the enterprise is clouded by its interest in serving political ends. Put another way, the members of the team most able to exert political pressure on the government will be able, through the government's holdings, to capture the board of directors.

The consequences of a corporate constituency capturing the board are noted by Blair and Stout. The "constituency could use its power over the board to seek rents opportunistically from other members of the productive team, thus discouraging team-specific investment." 197 In reference to a contested shareholder election in which all corporate constituencies have a voice, Blair and Stout ask that we "[i]magine the chaos ... likely to attend an election in which a firm's creditors, executives, rank-and-file employees, and other stakeholders with unique and often conflicting interests could vote on their favored candidates." 198 The chaos that they observe will take place under TARP, but rather than occurring through a corporate election it will occur within the political process of interest group pressure on the executive branch.

\section{F. Progressive Corporate Law Theory}

Progressive corporate law theory, part of the corporate social responsibility movement, defines the duty of directors and officers as to society at large, rather than to specific shareholder wealth maximization. Robert Reich analyzes one of the problems of requiring corporations to fulfill public interest functions and serve as a nexus for transfer payments

194 Id. at 274 (citing Raghuram G. Rajan and Luigi Zingales, Power in the Theory of a Firm, 113 Q.J. ECON. 387 (1998)).

195 See id. at 285

196 See id. at 288.

197 Id. at 292.

$198 \quad I d$ at 313. 
that would otherwise fit within the federal government's bailiwick. ${ }^{199}$ Employer-sponsored healthcare is government-subsidized through the tax code, and corporate social responsibility advocates fight for more expansive coverage. But Reich argues that the distortionary effects on the labor market from employer-sponsored healthcare make it an inefficient system. Reich also argues that "public scoldings" of corporations serve as a smokescreen by legislators to evade their responsibilities. ${ }^{200}$ Balancing the interests of so many divergent groups clouds the metric of success, which increases transaction costs for all concerned. Directors are able to play a bait-and-switch game with financial accountability: when earnings are down, directors can blame their investments in socially responsible goals; yet they can escape inconvenient social goals by pointing to the need to raise their earnings to obtain future capital to fund even more significant socially responsible commitments. As Bainbridge points out, "directors who are responsible to everyone are accountable to no one." 201 The executive agency overseeing its investment can subvert public transparency of its public role. ${ }^{202}$ The internal corporate policies of a private bank are not subject to Freedom of Information Act (FOIA).

Progressive corporate law takes issue with the very premise of the contractarian model. Bainbridge notes that one of William Bratton's arguments against the contractarian model is that the hypothetical bargains on which the theory relies may not have any one single equilibrium outcome, but rather face potentially multiple equilibria. ${ }^{203}$ Bratton's alternative requires judges to use flexible default rules that would examine fiduciaries' decisions ex post with reference to intuitive fairness. ${ }^{204}$

199 See Robert B. Reich, The Case Against Corporate Social Responsibility (Goldman Sch. of Pub. Policy Working Paper Series, Paper No. 08-003, 2008), available at http://ssrn.com/abstract=1213129.

200 Id. at 40-42.

201 Bainbridge, supra note 188 , at 582.

202 One critical theory of state ownership is concerned with managerial incentives. One aspect of the managerial view, from John Vickers and George Yarrow, is that states have a difficult time monitoring "enterprise managers." Alexander Muravyev, Federal State Shareholdings in Russian Companies: Origin, Forms and Consequences for Enterprise Performance 17 (Bank of Finland Inst. for Econs. in Transition, Discussion Papers, Paper No. 12, 2002) (citing JOHN VICKERS \& GeoRGE YARROW, PRIVATIZATION: AN ECONOMIC ANALYSIS (1988)), available at http://ssrn.com/abstract=1015707. David Skeel explains why governments may have an interest in keeping their definition of public interest goals vague when governing the firm managers that they oversee. See David A. Skeel, Jr., Virtual Privatization: Governance Reforms for GovernmentOwned Firms, 2 J. CORP. L. STUD. 82, 94 (2002). Even putting aside the fact that such objectives may not lend themselves to clear statement, government shareholders may not want to lose political flexibility by binding specific outcomes, and they may want to avoid binding specific deliverables to avoid criticism for failing to meet those goals after the fact. See id.

203 Bainbridge, supra note 167 , at 866 .

204 Id. at 866-67. 
Some progressive scholars also urge the necessity of communitarian values in setting up legal regimes. ${ }^{205}$ Bratton's iteration of progressive corporate law, and his critique of the contractarian model, focuses on the fact that the contractarians ignore the importance of trust and honor as abiding norms in governed relations between parties; Bratton terms this a mediative approach. ${ }^{206} \mathrm{He}$ rejects a formalistic approach that would mandate conformity to any one theory of the corporation, in the way that the contractarian approach does. ${ }^{207}$ Instead, he believes that a meditative legal decisionmaker, whether a judge or a regulator, would be able to conform corporate law to the shifting cultural and social norms of the time. ${ }^{208}$

One of the bones of contention between contractarians and progressives is that the contractarian approach considers only the result of hypothetical bargains without considering the events that actually led to that bargain. ${ }^{209}$ Yet in this context of a government control shareholder with immunity, the debate over whether there has been a bargain or not becomes somewhat irrelevant. There is no bargain. One shareholder has control and is immune from suit by the other shareholders, and any shareholder that does not have sufficient interest group energy to lobby for subsidies from the government is shut out of the bargain.

One of the challenges to government ownership is that government sets the rules that typically govern the disclosure of information between the company and its constituent groups. Governments habitually lift regulatory requirements for government-owned firms. Thus, accountability for running the firm becomes difficult no matter what normative theory of corporate law governs its affairs. This also places nongovernmental firms in a difficult position, as they are not privy to these same regulatory preferences. So even supposing that some readily identifiable metric for progressive objectives were available, it becomes questionable whether constituents of the corporation can actually trust disclosure of those metrics.

Stakeholder proponents also argue that firms are more productive when stakeholders have greater voice in corporate policy. ${ }^{210}$ There is some significant debate over this question in the literature. ${ }^{211}$ If it is true that

205 See id. at 873-74. Yet, the inherent conflict faced by the government as a shareholder would undermine this objective. The Treasury and Federal Reserve's actions in the JPMorgan/Bear Stearns and Bank of America/Merrill Lynch crises evidence those conflicts.

206 William W. Bratton, The Economic Structure of the Post-Contractual Corporation, 87 Nw. U. L. REV. 180, 212-13 (1992).

207 See id. at 212-14.

208 See id. at 214.

209 Bainbridge, supra note 167, at 865.

210 Id. at 878; Marleen A. O'Connor, The Human Capital Era: Reconceptualizing Corporate Law To Facilitate Labor-Management Cooperation, 78 CORNELL L. REV. 899 (1993).

211 See Thomas A. Kochan ET al., The TRANSFormation OF AMERICAN Industrial RELATIONS 153-77 (2d ed. 1994) (summarizing case studies showing generally positive but 
firms with greater employee and stakeholder participation are more productive, the evidence does not suggest that the presence of a government shareholder enhances productivity in this way. In fact, it suggests that government ownership in industry, particularly in banks, correlates with decreases in firm health, GDP growth, and access to credit. Interestingly, many noted progressive corporate law scholars reject nationalization of firms directly. ${ }^{212}$ Government ownership also seriously harms the government's justified role as the remedy for inefficient market externalities and unjust outcomes.

When an executive department becomes a controlling shareholder in public corporations, it can use those private companies as tools to support policies that would otherwise have to go through the political system of checks and balances. This means not having to go through Congress, including not having to submit to congressional review of budgetary legislation. ${ }^{213}$ It also means avoiding review of rulemaking by the courts. ${ }^{214}$ The government can point to efforts undertaken by the private firms it owns, but it can minimize accountability for those goals owing to its transparency and executive discretion free from judicial or congressional review.

\section{Implications for Corporate and Securities Practice}

\section{A. TARP Recipients Treated as Affiliates Under Securities Laws}

If the Treasury is a controlling shareholder in the companies participating in TARP, including the nation's eight largest banks, two hundred more banks, Chrysler, GM, and AIG, it may result in each of those companies being considered affiliates of each other as part of a controlled

variable results); Bainbridge, supra note 167 , at 879 (citing U.S. DEP'T OF LABOR, HIGH PERFORMANCE Work Practices and Firm Performance 5-9 (1993)). But see Raymond L. Hogler \& Guillermo J. Grenier, EMployee Participation and Labor LAW in the AMERican Workplace 103 (1992) (finding that "despite acclaim for the improved productivity achieved through employee participation and ['Quality Circles,'] the evidence to support the proposition is not altogether convincing, particularly in nonunion workplaces"); David I. Levine, Public Policy Implications of Imperfections in the Market for Worker Participation, 13 ECON. \& INDUS. DEMOCRACY 183, 185 (1992) (noting that most employee-involvement plans are unsuccessful, but claiming that those few following Levine's criteria succeed); Arnold E. Perl, Employee Involvement Groups: The Outcry over the NLRB's Electromation Decision, 44 LAB. L.J. 195, 204-06 (1993) (summarizing studies finding positive economic effects of those programs).

212 See, e.g., Bainbridge, supra note 167 , at 889.

213 For a more complete examination of how the government can use its interest as a shareholder to engage in off-balance sheet activities, and for a corollary argument for why the government should bring the debt of bailed-out entities in which the government owns an interest onto the federal government's books, see J.W. Verret, Separation of Bank and State: The Bailout Meets Federal Budget Law, BYU L. REV. (forthcoming 2011) (on file with the Yale Journal on Regulation).

214 See supra Part IV (discussing sovereign immunity for the government as a shareholder). 
group. ${ }^{215}$ This would then mean that any member of the group who sold securities held in any other member of the group may be required to abide by the strictures of Rule 144 in those transactions to avoid additional and burdensome prospectus and registration requirements. ${ }^{216}$

It may be the case that many, or possibly all, of the companies that have given the federal government shares in exchange for TARP funds are considered affiliates of each other. This has enormous implications for their ability to sell shares. Imagine if every time Goldman Sachs' proprietary trading operation wanted to sell shares in AIG, Citigroup, GM, or any of the other controlled TARP companies, many of whom are publicly traded and many of whom issue restricted securities through various exemption, Goldman Sachs had to register that sale as a public offering, deliver a prospectus, and be subject to section 11 liability for that registration.

A registration statement must be in effect for the sale of a security. ${ }^{217}$ Transactions by any person other than an issuer, underwriter, or dealer are exempt. ${ }^{218}$ An underwriter is defined as any person who has purchased from an issuer and any person controlling or controlled by the issuer. ${ }^{219}$ Rule 144 offers a safe harbor to being deemed an underwriter. ${ }^{220}$ TARP companies sharing the Treasury Department as a control shareholder risk their ability to make use of Rule 144 in their sales of securities of other firms that have given the Treasury securities, or at the very least will be required to comply with the information, holding period, and sales restrictions requirements of Rule 144 .

Any person who sells securities for the account of an affiliate may be constrained in their ability to sell securities of the affiliate under Rule 144 . An affiliate is defined as a person who controls, is controlled by, or is under common control with the person with whom he or she is affiliated.221 This definition captures the same concept that is used in the definition of control person under Rule 405 (c). ${ }^{222}$ Rule 405 defines control as the ability to influence, directly or indirectly, management decisions. ${ }^{223}$

In light of the SEC's interest in working with the Treasury Department in dealing with the financial crisis, combined with what has been described

215 See Securities Act $\S 2 a-11,15$ U.S.C. $§ 77 b(a)(11)(2006) ;$ see also 17 C.F.R. $\$ 230.405$ (2009) (defining "control").

21617 C.F.R. $\$ 230.144$ (2009).

217 Securities Act $\$ 5,15$ U.S.C. $\$ 77 e$ (2006).

$218 \quad$ ld. $\$ 4,15$ U.S.C. $\$ 77 \mathrm{~d}$.

219 Id. $\$ 2 \mathrm{a}-11,15$ U.S.C. $\$ 77 \mathrm{~b}(\mathrm{a})(11)$

220 This is vital, because the exemption found under section $77 \mathrm{~d}$ exempts a sale from the general registration requirement found in section $77 \mathrm{e}$ of the Securities Act only where an underwriter is not present.

2211 Thomas lee hazen, Treatise on the law of Securities Regulation 381 (4th ed. 2002); see also 17 C.F.R. $\$ 230.501$ (b) (2009).

222 HAZEN, supra note 221, at 381; see also 17 C.F.R. $\$ 230.405$ (2009).

22317 C.F.R. \$ 230.405(f) (2009). 
as the SEC's fight for its survival in the ongoing financial regulatory reworking, once this issue arises it would seem likely the SEC might be spurred to alter Rule 144 to ensure that this problem is avoided. However, the SEC does not have the explicit authority under the Exchange Act "to set the parameters of the section $4(1)$ and section 4(4) exemptions." 224 Thomas Hazen observes that Rule 144 is merely the SEC's interpretation of a statute, and not an actual exemptive rule. Thus the SEC's ability to alter exemptions in this area, and indeed Rule 144 itself, to protect trading by TARP affiliates does not have the same significance as an exemption given express statutory authorization. ${ }^{225}$ The SEC can also choose not to enforce registration and prospectus delivery requirements under this rule, but private plaintiffs have an express private right of action here that the SEC does not affect.

\section{B. Insider Trading}

Trading based on inside information is also a violation of Rule $10 \mathrm{~b}-5$ of the federal securities laws. ${ }^{226}$ And yet, section 3(c) of the Exchange Act effectuates an exemption for the U.S. government from, among other things, insider trading laws. ${ }^{227}$ The Treasury would nevertheless cause tremendous damage to the financial markets if it were to trade its TARP preferred shares using the voluminous inside information it possesses through its regulatory and market interactions with the banks participating in TARP. This discussion is not focused on issues of fairness in insider trading rules. ${ }^{228}$ Rather, as the debate has been more focused on the efficiency of insider trading, ${ }^{229}$ it will examine the efficiency of insider trading by the Department of the Treasury under the unique circumstances of TARP ownership.

Though they also frequently can access inside information from companies' interaction with state regulators, state pension funds are not immune from insider trading liability. The Alabama State Pension Fund

224 HAZEN, supra note 221 , at 452.

225 Although Hazen also notes that the SEC has general exemptive authority, Rule 144 was adopted prior to Congress's grant of general exemptive authority to the SEC. See id. at 452 nn.29-30.

226 See Securities Act § 7, 15 U.S.C. $\$ 77 \mathbf{j}(2006) ; 17$ C.F.R. $\S 240.10 b-1$ to .10b-21 (2009).

227 See Exchange Act $\$ 3 c, 15$ U.S.C. $\$ 78 c(c)$ (2006).

228 Roy A. Schotland, Unsafe at Any Price: A Reply to Manne, Insider Trading and the Stock Market, 53 VA. L. REV. 1425 (1967).

229 Macey explores some of the reasons why bringing ethical arguments into the insider trading debate seems to muddle the analysis. See Jonathan Macey, Ethics, Economics, and Insider Trading: Ayn Rand Meets the Theory of the Firm, 11 HARV. J.L. \& PUB. POL'Y 785 (1988); see also Victor Brudney, Insiders, Outsiders, and Informational Advantages Under the Federal Securities Laws, 93 HARV. L. REv. 322 (1979); Frank H. Easterbrook, Insider Trading, Secret Agents, Evidentiary Privileges, and the Product of Information, 1981 SUP. CT. REV. 309; Robert J. Haft, The Effect of Insider Trading Rules on the Internal Efficiency of the Large Corporation, $80 \mathrm{MICH}$. L. REv. 1051 (1982); Henry G. Manne, Insider Trading and Law Professors, 23 VAND. L. REv. 547 (1970). 
recently had to pay nearly a million dollars to the Liberty Group to settle a claim that they traded with the knowledge that Liberty was soon to receive a favorable licensing decision from another Alabama state agency. ${ }^{230}$

In Henry Manne's seminal text on insider trading, Insider Trading and the Stock Market, he argues that insider trading does not harm long-term investors, that it can serve as a useful compensation tool for executives, and that it contributes to the efficiency of stock market pricing. ${ }^{231}$ In his book, Manne considers the prospect of insider trading by government officials for their personal accounts, and he is critical of the practice. Manne also notes that government officials can, by virtue of their positions, obtain access to valuable information. ${ }^{232}$ Manne explains that they have advance information about corporate mergers, government contract approval, and regulatory product approval. ${ }^{233} \mathrm{He}$ also observes that executive officials may keep members of Congress informed about valuable information contained inside the government for the purposes of obtaining political favor, and that executives may do the same. ${ }^{234}$

He notes that one danger of trading by government officials is that they will change their regulatory approvals or their government contract selection processes merely to benefit their trades. ${ }^{235}$ The same principle could apply to when the Treasury owns shares as an institution, and is supported by evidence that governments tend to give regulatory preferential treatment to companies in which they own an interest. ${ }^{236}$

Manne notes that insider trading by government officials may also result in a net transfer of wealth from the market to government officials, implicating concerns about market efficiency in a way that typical insider trading does not. ${ }^{237}$ One counter to this argument may be that in the case of TARP companies, the use of insider information in trading ultimately benefits the taxpayer, and thus such a transfer is justified to help cover the cost of the taxpayer-funded bailouts. However, the dangers that the implicit discount the shares will experience during the time the company's health is under stress, and the accordant risk that it may obtain further bailout money as a result, may mitigate this justification.

230 Stephen Taub, Pension Fund Pays for Alleged Insider Trading, CFO.COM, Mar. 13, 2008, http://www.cfo.com/Article.cfm/10855944/c_10852358?f =TodayInFinance_Inside.

231 Henry G. Manne, Insider Trading: Hayek, Virtual Markets, and the Dog That Did Not Bark, 31 J. CORP. L. 167, 168 (2006) (summarizing the thesis of his book, HENRY G. MANNE, INSIDER TRADING AND THE STOCK MARKET (1966)).

232 MANNE, supra note 231, at 172.

233 Id. at 174-79.

234 Id. at $179-84$.

235 Id. at 178.

236 See, e.g., Daniel Berkowitz \& Yadviga Semikolenova, Privatization with Government Control: Evidence From the Russian Oil Sector 22 (William Davidson Inst. Working Papers, Paper No. 826, 2006), available at http://ssrn.com/abstract=920509.

237 MANNE, supra note 231, at 183-84. 
Some of those arguments would also apply to trades by government officials on behalf of the U.S. government, but few insider trading scholars could have foreseen that the government would take equity positions in much of the automotive and financial sectors. As such, this Section will consider the insider trading efficiency debate in light of that unique circumstance. While recognizing the depth and importance of scholarship challenging the logic of insider trading laws, and not taking issue with the observations of those scholars in the standard case, this Section will seek to counter use of those arguments to support insider trading by the government in its positions acquired through TARP. This situation involves some of Manne's original concerns about insider trading, but also encompasses a broader universe. The Treasury or the Fed can obtain information as government regulator, and also as control shareholder in these companies. The second avenue of information is a novel concern.

One of the global observations this Section will make is that any efficiencies that flow from insider trading by the Treasury would occur after its exit trade, and any costs would mostly be evidenced by a discount in the value of TARP shares prior to its exit trade-a time which also happens to coincide with the time during which the health of the TARP company is in jeopardy.

One fundamental difference distinguishing the analysis for the Treasury as a shareholder is that the benefits of insider trading are measured with the assumption that insiders will be able to engage in continuous trading. But the cost-benefit analysis in this situation will be distinctly different, as the Treasury only has limited authority to repurchase shares after it sells out its position. So this situation would likely involve one large exit trade, or perhaps a series of large exit trades by the government. The Treasury's decision to exit would also likely correlate with a determination that the financial crisis is over, as that is the Treasury's mandate under the EESA. So the time period that the Treasury still feels the financial crisis warrants its continuing to hold shares is also the time period over which the prospect of the Treasury's insider trading looms. Also, the fact that TARP insider trading will involve one or a limited number of discrete trades, after which it will not be permitted, and during which time other entities are prohibited from insider trading, will mean that any efficiencies enjoyed from that practice will be limited.

One of the prerequisites Manne observes is that in order for insider trading to cause no direct harm to investors, the trades should be made anonymously, which would not be true for the Treasury's trades. ${ }^{238} \mathrm{He}$ also observes that insider trading would not harm long-term investors, but admits that it may have mixed effects on short-term trading. ${ }^{239}$ While long-

238 Manne, supra note 231, at 168.

239 Id. at 169. 
term bias in securities markets may reduce volatility, and make costs to short-term trading less of a concern, this situation is unique. Shares in TARP firms were purchased under the bailout specifically with the assumption that the banks and other companies involved may be insolvent in the short term, and so the time horizon for both short-term and longterm investors may be the same. Further, for banks specifically, share price has now become an explicit element in the capital adequacy ratios used by the Treasury, the FDIC, and the Federal Reserve to measure bank health and institute corrective action. So during the period over which the Treasury holds its shares, any discount flowing from the prospect of insider trading by the Treasury would translate into regulatory penalties as well.

Arguments about using insider trading as a device to compensate executives ${ }^{240}$ would not be relevant in this context, as the Treasury does not offer performance-based compensation to its employees, and the Trust created by the Federal Reserve to manage its ownership in AIG also does not offer performance-based compensation to the trustees. As Manne notes, the arguments about using corporate insider trading as a compensation device do not apply in the context of government officials. ${ }^{241}$

Another issue with the Treasury as insider trader is that it has a much larger position in TARP firms than most shareholders. For instance, in Citigroup it holds a $34 \%$ position. The Treasury will trade in large blocks, making the effect on liquidity much more pronounced. This will be true whether the Treasury sells its shares into the general market or back to the company. Either way, it will affect either the short-term liquidity of the company in its ability to meet short-term obligations, or it will have a more significant impact on the liquidity of the market. Since the Treasury will not be able to keep its sales from becoming public knowledge, the effect may be more pronounced than much smaller inside trades occurring continuously over a longer period of time.

Harold Demsetz observes that insider trading may perform a useful function of compensating controlling shareholders for the positive externality of their minimizing agency costs for other shareholders through monitoring. ${ }^{242}$ At first blush this seems a relevant benefit, as the Article argues that the Treasury is a control shareholder in many of the firms obtaining money from TARP. But the government's interest in using the corporation to transfer wealth to interest groups, analyzed in this Article, would introduce agency costs of its own.

Manne also offers an argument that the predictive power of insider trading makes markets more efficient, relying in part on foundational

240 See id. at 172-73.

241 MANNE, supra note 231, at 182.

242 Harold Demsetz, Corporate Control, Insider Trading, and Rates of Return, 76 AM. ECON. REV. 313 (1986). 
principles from F.A. Hayek concerning the efficiency of the price system in promoting the flow of information. ${ }^{243}$ Two challenges will limit the phenomenon in the Treasury's case. First, and most importantly, Treasury officials are not playing with their own money and do not enjoy compensation from the trades. The career benefits they enjoy from the insider trading are likely to be significantly bounded, as for instance getting high praise for breaking even on TARP but experiencing diminishing marginal returns for TARP gains beyond that hurdle. Further, the career choices of Treasury officials, protected through civil service restrictions and limited in performance compensation, are likely to reflect a general tendency toward more pronounced risk aversion than for most other insider traders.

One of the counterarguments that Manne raises to the idea that insider trading may subject the stock market to manipulation is that informed traders, or as he calls them "counter-manipulators," would be able to counterbalance the effect of manipulators. ${ }^{244}$ While this may hold in the general case, the Treasury is a much larger control shareholder than most other insider traders, as was previously explored. Thus the Treasury's inside trades may be expected to strain the budget constraints of the counter-manipulating traders.

One argument Dennis Carlton and Daniel Fischel raise against insider trading laws is that if a company permitting insider trading were engaging in activity that was harmful to other shareholders, then its shares would trade at a discount in comparison to other companies. ${ }^{245}$ In this case, I do argue that shares in TARP firms will trade at a discount due to the prospect of insider trading by the government, but a couple of things about this situation are distinct from the hypothetical bargain raised by Carlton and Fischel. First, the insider trading is done by a controlling shareholder, in a market in which insider trading by all other shareholders is prohibited. The control shareholder would therefore have no incentive to change the rules if it thought its profits from insider trading were greater than the general discount under which the shares trade. Second, this control shareholder purchased shares during an economic recession as part of a bailout. Third, this shareholder also has an interest in causing the underlying firm to engage in non-profit-maximizing activities that subsidize interest groups. As such, the government may be able to recoup some of the losses in the value of its shares flowing from the subsidizing activity specifically by insider trading. Finally, the control insider will engage in one or a small series of exit trades, after which it will exit the

243 Manne, supra note 231, at 181-83. Further, as previously mentioned, the Treasury's interest in insider trading would be more bounded than that of other insider traders.

244 See id.

245 Dennis W. Carlton \& Daniel R. Fischel, The Regulation of Insider Trading, 35 STAN. L. REV. 857, 860 (1983). 
market for good. Consequently, the incentives of the controlling shareholder in TARP companies are distorted in a way that prevents the implicit bargain that Carlton and Fischel use to undermine the justification for more general insider trading laws.

Carlton and Fischel also note one benefit of insider trading is that it permits continuous, rather than discrete, flows of information. ${ }^{246}$ This benefit would not apply in this situation, again because the Treasury's exit trades would be a one-time event. Carlton and Fischel also posit that insider trading can help deal with the problem of renegotiating agency contracts, and offer that the possibility of insider trading allows for more efficient effective renegotiation of executive compensation, incentivizing managers to continue to develop and acquire appropriate investment opportunities. ${ }^{247}$ Again, this would not work for agency bureaucrats, as their rewards for trading would be more attenuated and bounded. Further, remember that any efficiencies that result will be from one discrete trade. Also, Carlton and Fischel note that executives attracted to insider trading as compensation would likely be those who are the least risk-averse. ${ }^{248}$ As noted previously, bureaucrats as a group are likely to be more risk-averse, having chosen a profession with lower risk and rewards than the private sector executives in whose companies their department owns shares.

\section{State Corporate Law}

In looking to state corporate law a focus on Delaware is appropriate, as many TARP participants, including Citigroup, are incorporated in Delaware. ${ }^{249}$ This Section will examine the rights that the Treasury has as a shareholder in TARP firms. It will examine the obligations that the Treasury would have as a control shareholder were it not for the sovereign immunity protection that the Treasury enjoys. It will also consider how the presence of a control shareholder with sovereign immunity can complicate the existing state corporate law rights and obligations for boards, shareholders, and executives at TARP firms that do not enjoy sovereign immunity.

The Treasury certainly has the option to bring an action in Delaware to pursue its state law shareholder rights. Shareholders are granted certain rights by the corporate laws of a company's state of incorporation. Sixty percent of the Fortune $\mathbf{5 0 0}$ have chosen Delaware as their state of incorporation. Under Delaware law, shareholders have the right to sue the directors of a company for violations of their fiduciary duties as directors. They also have the right to seek an injunction of corporate mergers, seek

249 Exchange Agreement, supra note 58, at 6, 12. 
appraisal of the value of their shares in certain instances, and seek inspection of the books and records of a corporation. 250 These litigation rights will also need to be considered very carefully by the Treasury, and much of the analysis concerning participation in federal securities class actions will also apply to the Treasury's exercise of its state law shareholder rights. The Treasury's right to litigate will not be limited to its common equity; indeed, its preferred stock in hundreds of other TARP recipients gives it the same rights as common shareholders. ${ }^{251}$ One complication that the Treasury may face in its exercise of shareholder rights is that it may face conflicts in the exercise of those rights. For instance, it may be the controlling shareholder of multiple defendants in a suit, or it may be a controlling shareholder in companies on opposite sides of a suit. Indeed, this conflict may be present for a number of types of litigation outside of the corporate governance context.

The Treasury has previously shown a disregard for the consequences of state corporate law in its conduct of the bailout. Steven Davidoff and David Zaring observe that deal protection devices included in the JPMorgan/Bear Stearns merger facilitated by the Treasury included forcethe-vote provisions that likely ran afoul of Paramount v. QVC, Blasius, and Unocal. ${ }^{252}$ It may also be the case that Delaware intentionally avoids having to face issues of corporate law that may interfere with federal policy in the midst of financial crisis. For instance, Marcel Kahan and Ed Rock observe that Delaware's review of the Bear Stearns deal, in which Vice Chancellor Donald Parsons declined to review the underlying deal, represented a strategic decision by the Delaware courts not to allow corporate law to interfere in the government's execution of the bailout. ${ }^{253}$ However, litigation concerning Bank of America's purchases of Merrill Lynch and Countrywide are ongoing, so in that sense we can see that being a party to the financial crisis does not give one carte blanche. ${ }^{254}$ As such, with the nadir of the financial crisis behind us, we can expect that issues of

250 See William Allen, Reinier H. KraAkman \& Guhan Subramanian, Commentary and CASES ON THE LAW OF BUSINESS ORGANIZATION 369, 453, 484 (2007).

251 See DEL. CODE ANN. tit. 8, §327 (2006).

252 Paramount Commc'ns, Inc. v. QVC Network, Inc., 637 A.2d 34 (Del. 1994); Unocal Corp. v. Mesa Petroleum Co., 493 A.2d 946 (Del. 1985); Blasius Indus., Inc. v. Atlas Corp., 564 A.2d 651 (Del. Ch. 1988); see also Steven M. Davidoff \& David Zaring, Regulation by Deal: The Government's Response to the Financial Crisis, 61 ADMIN. L. REv. 463, 481 (2009).

253 Marcel Kahan \& Edward Rock, How To Prevent Hard Cases from Making Bad Law: Bear Stearns, Delaware, and the Strategic Use of Comity, 58 EmoRY L.J. 713 (2009). If the Delaware Court of Chancery would actually seek to avoid interfering with the bailout, that might give the Treasury an advantage in litigation in Delaware. Then again, once the national financial crisis cools down it may limit any incentive in favor of comity. Also, the Delaware Court of Chancery's decision in County of York Employees Retirement Plan v. Merrill Lynch \& Co., No. 4066-VCN, 2008 WL 4824053 (Del. Ch. Oct. 28, 2008), suggests that Delaware is not unwilling to apply standard principles of corporate law in adjudicating shareholder rights despite a firm's presence in the center of the financial crisis.

254 See In re Countrywide Corp. S'holders Litig., No. 3464-VCN, 2009 WL 2902476 (Del. Ch. Aug. 28, 2009); County of York Employees Retirement Plan, 2008 WL 4824053. 
corporation law will be important despite the Treasury's insistence on ignoring them and despite the appearance to some that, in one case, Delaware made a strategic decision to stay out of the mix.

Under state corporate law, shareholders that are deemed to be in control of the corporation have a fiduciary duty to other shareholders in the corporation. This means that if they use their influence over the company to cause changes in corporate policy that harm the other shareholders in the corporation, the control shareholders become liable to the other shareholders. In particular, control shareholders that exercise their powers out of an interest other than the best interest of the company and its shareholders can face liability for violation of the duty of loyalty. This notion is most famously explored in Sinclair Oil Corp. v. Levien, in which the Delaware Supreme Court ruled that where a controlling shareholder receives something from a controlled corporation to the exclusion, and the detriment, of the other shareholders in the company, that shareholder will then be deemed to be self-dealing, and the shareholder will face the burden of proving the entire fairness of that business decision. ${ }^{255}$ That standard has subsequently expanded to one that applies the rigorous entire fairness standard to all transactions in which the controlling shareholder obtains a benefit not shared by all shareholders. ${ }^{256}$

In the Treasury's case, such a benefit could for example be obtained in a case in which an interest group to which the Administration feels politically beholden obtains a benefit from the corporation that other shareholders do not share. This could be through subsidized mortgages, a decision to keep a dealership open despite it being a net loss to the company, or a decision to open factories in districts of politically powerful congressmen.

The fact that the Treasury is not constrained by control person liability means that it is not constrained by law the way that the other shareholders, directors, and officers are constrained. Regardless of what reforms should be instituted in legal regimes, introducing a new player into an existing structure with the power to trump the other players with its sovereign immunity from the rules of the game will cause enormous damage to the economic relations between the various players. It would be like a group of people playing Monopoly when one of the players has the right to ignore the rules of the game. The other players will either refuse to play, or turn to lobbying the one player for residual profits rather than playing the game by its rules.

The Treasury's immunity may also support immunity for directors it supports, but only if they are deemed government officials. E. Norman

255 Sinclair Oil Corp. v. Levien, 280 A.2d 717, 720 (Del. 1971).

256 Mary Siegel, The Erosion of the Law of Controlling Shareholders, 24 DEL. J. CORP. L. 27, $67-70$ (1999). 
Veasey and Christine Di Guglielmo outline some iterations of constituency directors: directors designated by creditors, venture capitalists, labor unions, controlling shareholders, preferred shareholders, and other special shareholder voting arrangements. ${ }^{257}$ Veasey and Di Guglielmo observe that "bet the company" scenarios, where the continued existence or a substantial percentage of the assets of a company are at stake, will be particularly prone to conflict between the interests of the corporation and the interests of the shareholders. ${ }^{258}$

If the government merely uses its implicit leverage as control shareholder, and as guarantor, to encourage the board to take action, those directors will still be subject to fiduciary duty review. This means that private litigants would be able to enjoin director action that violated their fiduciary duty even though they are unable to enjoin the Treasury directly because of the EESA. One factor which may also protect constituency directors in this context would be if they constitute a minority of the board of directors, and therefore escape liability where the majority of directors in a transaction are disinterested. ${ }^{259}$ Nevertheless, the existence of a control shareholder may result in a problem for the individual director's status as disinterested, even though the government remains immune from liability. If the constituency director shares information with the represented constituent it may also run into liability for violation of its fiduciary duty. 260

The biggest hurdle to holding the individual, government-constituent directors accountable for actions they may take under the direction of the Treasury as controlling shareholder is that, in a perverse way, the presence of the government as shareholder may give the individual directors the protection of the business judgment rule. The individual directors can assert a credible claim that they acquiesced to the Treasury's demands because the threat of retaliatory regulation from the Treasury or the other financial regulators, or the threat that the firm would be excluded from any subsequent participation in government loans or bailouts, could actually make acquiescence by the individual directors the best decision for the company. As such, the business judgment rule would protect that decision. Therefore, holding the individual directors who are chosen by the government liable would not be an effective substitute for an action against the government controlling shareholder.

One important consequence of being a controlling shareholder is that a controlling or dominating shareholder standing on both sides of a transaction, as in a parent-subsidiary context, bears the burden of proving

257 E. Norman Veasey \& Christine T. Di Guglielmo, How Many Masters Can a Director Serve? A Look at the Tensions Facing Constituency Directors, 63 Bus. LAW. 761, 763 (2008).

$258 \quad$ Id. at 765.

259 Id. at 773.

260 Id. at 775. 
its entire fairness. ${ }^{261}$ With respect to the standard of review for cash-out mergers by a control shareholder, Kahn $v$. Lynch provides that:

[T] he exclusive standard of judicial review in examining the propriety of an interested cash-out merger transaction by a controlling or dominating shareholder is entire fairness. The initial burden of establishing entire fairness rests upon the party who stands on both sides of the transaction. However, an approval of the transaction by an independent committee of directors or an informed majority of minority shareholders shifts the burden of proof on the issue of fairness from the controlling or dominating shareholder to the challenging shareholder-plaintiff. ${ }^{262}$

The independence of special committees that are charged with negotiating interested transactions, who are supposed to prevent the defendant from being faced with the onerous burden of entire fairness, can become more difficult to establish by virtue of the presence of a control shareholder. The Delaware Court has held that "unless the controlling or dominating shareholder can demonstrate that it has not only formed an independent committee but also replicated a process 'as though each of the contending parties had in fact exerted its bargaining power at arm's length,' the burden of proving entire fairness will not shift." 263 Through its sovereign immunity, the Treasury can escape damages awards for violations of its fiduciary duty to shareholders. However, the Delaware courts can still use their equity power to set aside or enjoin transactions which result from violations of the controlling shareholder's fiduciary duty.

Consider, for instance, that consolidation through merger is a frequent method by which banks grow. Moreover, when banks are on the verge of liquidation, the Comptroller, the FDIC, and the Fed tend to try to facilitate a merger or acquisition of the troubled bank to avoid exposing the FDIC to

261 Weinberger v. UOP, Inc., 457 A.2d 701, 710 (Del. 1983); see Rosenblatt v. Getty Oil Co., 493 A.2d 929, 937 (Del. 1985).

262 Kahn v. Lynch Commc'n Sys., Inc., 638 A.2d 1110, 1117 (Del. 1994) (citing Weinberger, 457 A.2d at 710-11, and Rosenblatt, 493 A.2d at 937-38).

263 Weinberger, 457 A.2d at 709-10 n.7. The Delaware courts have also held that "[ $\mathrm{t}] \mathrm{he}$ potential for coercion and unfairness posed by controlling stockholders who seek to acquire the balance of the company's shares by acquisition requires some equitable reinforcement, in order to give proper effect to the concerns undergirding Lynch. In order to address the prisoner's dilemma problem, our law should consider an acquisition tender offer by a controlling stockholder noncoercive only when: (1) it is subject to a non-waivable majority of the minority tender condition; (2) the controlling stockholder promises to consummate a prompt $\S 253$ merger at the same price if it obtains more than $90 \%$ of the shares; and (3) the controlling stockholder has made no retributive threats." In re Pure Resources, Inc., S'holders Litig., 808 A.2d 421, 445 (Del. Ch. 2002). Delaware courts have also found that "the majority stockholder owes a duty to permit the independent directors on the target board both free rein and adequate time to react to the tender offer, by (at the very least) hiring their own advisors, providing the minority with a recommendation as to the advisability of the offer, and disclosing adequate information for the minority to make an informed judgment. For their part, the independent directors have a duty to undertake these tasks in good faith and diligently, and to pursue the best interests of the minority." Id. 
substantial drawdowns. Indeed, an acquisition is often considered preferable to a resolution because the response from counterparties and depositors to a merger rather than a liquidation is better for the overall health of the troubled bank. A case in point is the situation in which Bank of America seems to have been pressured to follow through with its acquisition of investment bank Merrill Lynch. ${ }^{264}$

This offers one potential avenue for Chancery jurisdiction that would not need participation by the controlling shareholder. Despite the fact that the federal government is immune, the corporation itself is not, and therefore theoretically the Court of Chancery could still enjoin the company from engaging in particular transactions even if it could not hold the control shareholder liable for doing them. But then again, determining that the action was the result of government pressure would remain difficult, as the government control shareholder is able to evade participation in the suit and could thus simply ignore subpoenas for information. Further, this would only work for challenging transactions that have not been substantially completed.

Robert J. Rhee raises an interesting point about a little known provision of the Delaware General Corporation Law (DGCL) which seems to speak to the question. He notes that section 122 of the DGCL, which specifies the powers of corporations, lists two enumerated powers that do not necessarily comport with long-term maximization of shareholder wealth, and may in fact permit activities in service of the greater social welfare that may be harmful to the corporation. ${ }^{265}$ Section 122(9) of the DGCL permits corporations to "make donations for the public welfare or for charitable, scientific, or educational purposes, and in time of war or national emergency in aid thereof." 266 Rhee also notes that section $122(12)$ gives a corporation the power to "transact any lawful business which the corporation's board of directors shall find to be in aid of government authority." 267

Rhee argues that since charitable donations may harm the corporation, boards with government shareholders can look to 122(9) to justify their decision to make "donations" through corporate policy decisions determined by their government shareholder to be in the public interest. ${ }^{268}$ First, it should be noted that 122(9) is bounded by a rule of reason limitation. ${ }^{269}$ As such, it could not justify actions that substantially put the value of the corporation in jeopardy as, for instance, the Bank of

264 See generally Robert J. Rhee, Fiduciary Exemption for Public Necessity: Shareholder Profit, Public Good, and the Hobson's Choice During a National Crisis, 17 Geo. MASON L. Rev. 661 (2010).

265 See id. at 701.

266 Del. CoDE ANN. tit. 8, $\$ 122(9)$ (2008).

267 Rhee, supra note 264, at 704 (quoting DEL. CODE ANN. tit. 8, § 122(12) (2008)).

268 Id. at 701.

269 See Theodora Holding Corp. v. Henderson, 257 A.2d 398 (Del. Ch. 1969). 
America/Merrill Lynch merger that Rhee describes. Rhee argues that since Delaware courts have upheld particularly large executive compensation payouts, they can be expected to uphold large donations, but that suggestion is untenable as the two are entirely distinct legal questions for dissimilar purposes and governed by distinct threads of authority. ${ }^{270}$

Second, any power specifically granted to shareholders or the board is itself limited by the fiduciary duty of the members of the board, which is to say that, despite an affirmative grant of power in the DGCL, the Delaware courts have shown a marked willingness to find use of that power to be in abrogation of the director's fiduciary duty. ${ }^{271}$ This limitation would thus apply to both $122(9)$ and $122(12)$.

Third, Rhee seems to accept that the recent financial crisis was a "national emergency" such that it justifies application of either of these two sections. It is not, however, clear from reading the legislative history of that section that the Delaware legislature intended 10\% unemployment and the decline in the stock market we saw in September 2008 to count as a "national emergency." The Folk Report on the 1967 amendments to the DGCL explains the purpose behind 122(12) and the "in time of war or national emergency" phrase from $122(9) .{ }^{272}$ That explanation reads as follows:

\begin{abstract}
Many states specifically authorize a corporation, irrespective of the purposes stated in the certificate of incorporation, to do any lawful business in time of war or other national emergency. Its effect is to eliminate the necessity for a formal amendment of the certificate, by shareholder action; and in war or emergency times, especially in a nuclear age, this may be important. Accordingly, Delaware should, of all states, make this power clear and unmistakeable, and protect its corporations in the exercise thereof. Delaware's recognition of emergency situations is reflected by its enactment of the emergency bylaws provision. ${ }^{273}$
\end{abstract}

The emphasis on nuclear attack as a central reason behind this provision in the DGCL puts the question into clearer perspective. Though the stock market crash of September 2008 was a major market event, no one-day decline in the S\&P 500 even ranked within the top ten highest percentage declines in history. ${ }^{274}$ By Rhee's definition, we may expect to see a "national emergency" every five to ten years. And even if the events of

270 See Rhee, supra note 264 , at 703-04.

271 See Schnell v. Chris-Craft, 285 A.2d 437 (Del. 1971).

272 See, e.g., ERNEST Folk, REPORT OF THE DELAWARE CORPORATE LAW REVISION COMMITTEE 40 (1967), available

at http://law.widener.edu/LawLibrary/Research/OnlineResources/DelawareResources/DelawareC orporationLawRevisionCommittee.aspx.

273 ld. (internal citations omitted).

274 Alexandra Twin, Stocks Crushed, CNNMoney.com, Sept. 29, 2008, http://money.cnn.com/2008/09/29/markets/markets_newyork/index.htm. 
September 2008 were a national emergency, it is not clear that the Treasury's actions as a shareholder in 2009 and onward occurred during a time of national emergency such that these special provisions of the DGCL should continue to apply.

\section{Shareholder Voting}

One of the basic rights afforded to shareholders is the right to vote in elections for the board of directors. That right establishes the basis for the balance of power between shareholders and the management of the company. Pursuant to the purchase agreements and changes to TARP participants' charters, the preferred shares purchased through the CPP are non-voting shares. ${ }^{275}$ However, the Treasury retains significant leverage to affect board decisions for firms participating in TARP.

One exception to the federal government's agreement not to vote its TARP preferred shares is a provision permitting the holder of the preferred shares to nominate two "preferred directors" to the board in the event that the participating firm falls behind on its preferred dividend payments for six successive quarters. ${ }^{276}$ The Treasury preferred shares also retained the right to vote on any mergers or exchange activity and on new issuance of shares. In addition, the government mandated certain corporate governance changes for firms participating in TARP. Assuming that the Treasury maintains the legal authority to waive those provisions, it could offer to do so in exchange for other changes in corporate policy.

More important to this analysis is the Treasury's decision to permit TARP participants to convert their preferred stock into common voting equity. Citigroup has accepted this, and other banks might as well. Collective action constraints and rational apathy by shareholders, particularly retail investors, can leave shareholders with as little as 30$40 \%$ of voting equity with the ability to control the board. ${ }^{277}$ That means that the Treasury may be able to control the board in most any TARP bank, particularly any of the nine largest banks, that converts its TARP preferred shares into common voting equity.

In 2003 and 2007, the SEC considered proposals to include shareholder nominees on the corporate ballot. ${ }^{278}$ Though it ultimately

275 See supra Part II for background information on TARP.

276 See Press Release, U.S. Dep't of the Treasury, TARP Capital Purchase Program: Senior Preferred Stock and Warrants 3 (Oct. 14, 2008), available at http://treas.gov/press/releases/reports/document5hp1207.pdf.

277 See In re Cysive, Inc., S'holders Litig., 836 A.2d 531 (Del. Ch. 2003).

278 For a summary of the battle for shareholder representation on corporate boards, and the arguments on either side, see J.W. Verret, Pandora's Ballot Box, or a Proxy with Moxie? Majority Voting, Corporate Ballot Access, and the Legend of Martin Lipton Re-Examined, 62 BuS. LAW. 1007 (2007). 
failed, the SEC is currently considering a new access proposal. ${ }^{279}$ Though the Treasury has given up voting rights in the preferred shares that it holds, that does not necessarily mean that it has given up the right to nominate prospective directors for other shareholders to vote on under a future SEC proxy access rule. The Treasury will certainly be able to nominate candidates for banks in which it holds common voting equity, and would not need even to hold a controlling stake in that circumstance.

Governments can make particularly active shareholders. For example, state comptrollers and treasurers were the most vocal advocates of shareholder proxy access when the 2003 reform proposal was under consideration. ${ }^{280}$ Roberta Karmel asserts that state-run pension funds and labor unions have been more willing to fight to obtain influence over the corporate ballot than mutual funds or other financial intermediaries. ${ }^{281}$

\section{E. Securities Class Actions}

Section $3(c)$ of the Exchange Act exempts the federal government from coverage of the Act. ${ }^{282}$ But most of those suits are prosecuted by private plaintiffs who have been granted an implied private right to sue that is shared with the SEC. The implied private right of action under Rule $10 \mathrm{~b}-5$ is a creation of judicial fiat. So even though the Treasury is likely not subject to Rule $10 \mathrm{~b}-5$ because of section $3(\mathrm{c})$, it may still be able to exercise its implied private right of action.

The right to join in, and in some cases serve as lead plaintiff in, private litigation against firms covered by the federal securities laws for violations of disclosure laws, registration requirements, fraud provisions, and other rules is a powerful one. According to Cornerstone Research, since 1999 roughly a hundred federal securities class actions have settled every year with an aggregate value that tends to track anywhere from one to ten billion dollars. ${ }^{283}$ In some blockbuster years that amount is higher, such as in 2006, when the securities plaintiffs bar recovered over eighteen billion dollars (nearly half of which was a result of the Enron case). ${ }^{284}$

279 Facilitating Shareholder Director Nominations, Securities Act Release No. 9046, Exchange Act Release No. 60,089, Investment Company Act Release No. 28,765, 74 Fed. Reg. 67,144, available at http://www.sec.gov/rules/proposed/2009/33-9046.pdf (proposed Dec. 18, 2009).

280 Roberta S. Karmel, Should a Duty to the Corporation Be Imposed on Institutional Shareholders?, 60 Bus. LAW. 1, 17 (2004).

281 Id.

282 See supra Section VI.B on insider trading.

283 Ellen M. Ryan \& LaUra E. Simmons, Cornerstone Research, Securities Class ACTION SETTLEMENTS: 2008 REVIEW AND ANALYSIS 1 (2009), available at http://securities.stanford.edu/Settlements/REVIEW_1995. 2008/Settlements_Through_12_2008.pdf.

284 Id. 
Institutional investors are the lead plaintiff in almost $60 \%$ of securities class action settlements. ${ }^{285}$ The other plaintiffs in the class rely on the lead plaintiff to manage the litigation on their behalf and look out for their best interests. As the largest shareholder in the financial services and automotive sectors, the Treasury may have to face the prospect of getting involved in securities class actions.

To get an idea of the potential size of this activity, the California Pension Fund ("CalPERS") provides a useful comparison. In 2009, CalPERS had roughly $\$ 180$ billion dollars in total net assets, less than half the current cost of TARP investments. ${ }^{286}$ In 2008 alone CalPERS recovered at least $\$ 925$ million dollars through serving as lead plaintiff in securities class action litigation. ${ }^{287}$ Given that TARP investments could increase, and that the financial services sector is more prone to litigation risk owing to its place at the center of the economic recession, Treasury participation in federal securities class actions could potentially amount to billions of dollars per year.

One relevant question that should be considered is whether the Treasury would be an appropriate lead plaintiff. Is there a conflict when the government has an interest in the long-term health of the defendant? Typically lead plaintiffs do not have an incentive to help the defendant, but the federal government's interest in prevention of systemic stress to the banking system may compromise the Treasury's suitability as a lead plaintiff. 288

One argument against the Treasury exercising its shareholder litigation rights is that it would be a bad idea to sue banks that are already under severe stress such that they pose a systemic threat to the health of the nation's banking system. The counterargument would be a new

285 Id. at 11.

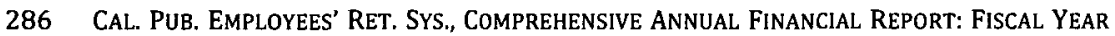
ENDED JUNE 30, 2009, at 6 (2009), available at https://www.calpers.ca.gov/msspublication/pdf/xAeMFz6gx0PeW_calpers-cafr-2009.pdf.

287 See Press Release, Cal. Pub. Employees' Ret. Sys., CalPERS Recovers \$30 Million from Former UnitedHealth Group CEO (Sept. http://www.calpers.ca.gov/index.jsp?bc=/about/press/pr-2008/sep/recovers-30-millionunitedhealth.xml.

288 Another open question is who will manage these litigation rights. Will the Department of Justice (DOJ) or the SEC play a role? The DOJ and the SEC have expertise in securities fraud enforcement, which is a form of litigation relatively similar to private litigation, but there is a conflict here as well. Plaintiffs typically piggyback on SEC enforcement actions. For instance, almost $25 \%$ of settled securities class actions since 1996 have also involved companion SEC actions, and the median recovery of private actions tends to double when the SEC is also involved. RYAN \& SIMMONS, supra note 283 , at 13 . Would the agency that is charged with managing these rights contract out the representation to a private plaintiff? This may be fraught with controversy, as the securities class action bar is a generous donor to political campaigns. Another interesting question is whether the Private Securities Litigation Reform Act, which governs the rights of lead plaintiffs in federal securities class actions, should be changed in light of the fact that the federal government may become the dominant player in securities litigation. Should there be any safe harbors in light of the fact that TARP purchases are intended to ensure the health of the nation's banking system? 
iteration of the moral hazard argument common to banking and insurance regulation: a bank may have carte blanche to violate the securities laws if it knows that its control shareholder will not penalize the bank by instituting litigation out of fear of harm to the financial system.

There are a number of mechanical issues with the Treasury acting as a securities plaintiff. First, damages in securities class actions are measured in a number of ways, depending on the type of news that triggers the action. It could be triggered by news causing the share price to rise, in which case those that sold during the fraud period suffer harm, or it could be triggered by news that causes the share price to fall, in which case those who bought during the fraud period can sue for the harm they have suffered. ${ }^{289}$ The standard method for awarding damages in the event of bad news "is to award the difference between the price paid by the buyer and the market price after [the] corrective disclosure." 290

Concerns of systemic interest would argue against government participation in "bad news" securities class actions for troubled firms if the class action award itself risks the long-term viability of the firm. One exception would be class actions instituted after the underlying bank has entered liquidation, in which case the effect of the class action on the bank is no longer a problem. Richard Booth has argued that efficiency losses from shareholder class action litigation make them more trouble than they are worth. ${ }^{291} \mathrm{He}$ observes a downward spiral effect-that the prospect of payout causes the stock price to fall more than it would otherwise, which increases the expected payout, which increases the stock's price decrease, and so forth. 292

One of the elements required of shareholder plaintiffs that may be difficult for the Treasury to show is reliance on the securities law violation in deciding whether to buy or sell. According to Karmel, "[ $t$ ]he reliance requirement is frequently presumed in [Rule 10b-5] cases based on the efficient capital market hypothesis." 293 The reliance requirement is frequently treated synonymously with a requirement of transaction causation. ${ }^{294}$ Basic $v$. Levinson adopted the fraud-on-the-market theory to permit a presumption of reliance, on the theory that efficient markets would incorporate all publicly available information into changes in price, and price is a central element in the decision of whether or not to buy a

289 Richard A. Booth, Taking Certification Seriously - Why There Is No Such Thing as an Adequate Representative in a Securities Fraud Class Action 2 (Villanova Univ. Sch. of Law, Public Policy Research Papers, Paper No. 2008-07, 2008), available at http://ssrn.com/abstract=1026768.

290 Id.

291 Id. at 3.

292 Id.

293 Roberta S. Karmel, When Should Investor Reliance Be Presumed in Securities Class Actions?, 63 BuS. LAW. 25, 26 (2007).

294 Id. at 33. 
security. ${ }^{295}$ The fraud-on-the-market theory does not require the complete establishment of reliance, but rather serves as a presumption which can be rebutted by showing that the plaintiff would have purchased the securities even if the truth were known. ${ }^{296}$ This may make it difficult for the Treasury to join in actions alleging misstatements in TARP participants' financial statements that hid bad news, since it is likely that the Treasury purchased shares precisely because they were decreasing in value and would have done so sooner if bad news were released earlier. The Treasury may not face this issue, however, if it sues on the basis of sales prior to the release of good news. Fannie Mae ran into some difficulty with allegations of earnings management-that it smoothed earnings to hide good results. ${ }^{297}$ If banks engage in a similar strategy, the Treasury may be able to join in those actions after it sells its TARP shares.

In addition, Dura Pharmaceuticals v. Broudo holds that plaintiffs must also establish loss causation in addition to transaction causation. ${ }^{298}$ Loss causation relates to proof of economic harm, whereas transaction causation requires proof that the violation caused the plaintiff to engage in the transaction in question. Central Bank v. First Interstate Bank and Stoneridge $v$. Scientific-Atlanta both also leave open some potential for the Treasury Department to sue non-primary actors beyond the TARP recipients in which the federal government is invested as primary actors. ${ }^{299}$

\section{Proposed Solutions}

This Article will now close with three recommendations that would begin to remedy the problems it has discussed.

295 Basic v. Levinson, 485 U.S. 224 (1988).

296 In re Kmart Corp. Sec. Litig., No. 95-CS-75584-DT, 1996 WL 924811, at *1 n.9 (E.D. Mich. Dec. 16, 1996) (citing Basic, 485 U.S. at 248 n.27); see also 2 HAZEN, supra note 221, $\S$ 12.10 , at 504 .

297 Jonathan D. Glater, Freddie Mac Understated Its Earnings by $\$ 5$ Billion, N.Y. TIMES, Nov. 22, 2003, available at http://www.nytimes.com/2003/11/22/business/freddie-macunderstated-its-earnings-by-5-billion.html?pagewanted=all.

298 Dura Pharm., Inc. v. Broudo, 544 U.S. 336, 341-46 (2005).

299 See Karmel, supra note 293, at 47-48; see also Stoneridge Inv. Partners, LLC v. Scientific-Atlanta, Inc., 552 U.S. 148 (2008); Cent. Bank of Denver, N.A. v. First Interstate Bank of Denver, N.A., 511 U.S. 164 (1994). Typically the exposed players include investment banks and accountants. With respect to the investment banks, the Treasury will face a conflict as it likely holds control positions in those banks as well. With respect to the accountants, the Treasury might have more flexibility. Another curious consequence of the Treasury's TARP holdings involves SEC Fair Fund distributions. The SEC can use civil monetary penalties and enforcement settlements to establish a "Fair Fund" for the benefit of victims of securities violations. If the victim turns out to be the Treasury Department, will the SEC be as active in seeking Fair Funds? For an example of a Fair Fund distribution, see Press Release, Sec. \& Exch. Comm'n, SEC Announces Distribution of $\$ 60$ Million Fair Fund to MBIA Investors Harmed by Accounting Fraud (Mar. 27, 2009), http://www.sec.gov/news/press/2009/2009-69.htm. 


\section{A. Fiduciary Duties for the Federal Government as Shareholder}

Control person liability under state corporate law would be rare for pension funds and mutual funds, since ERISA and mutual fund regulations prohibit owning more than a certain threshold in companies, ${ }^{300}$ but if somehow a pension or mutual fund did own a controlling stake it would be subject to fiduciary duties in its exercise of shareholder control. ${ }^{301}$ ERISA and the federal securities laws impose fiduciary duty responsibilities on private pensions and mutual fund managers, respectively. ${ }^{302}$ Further, state codes often govern fiduciary responsibilities involving state pension funds.

CalPERS, for instance, is subject to a codified fiduciary requirement in the California Constitution. CalPERS is subject to a requirement to act for the exclusive purpose of providing benefits to participants and beneficiaries, and to engage in a prudent process for making all decisions related to the operation of the plan, including decisions related to the plan's investments and services. ${ }^{303}$ The prudent person standard governs. ${ }^{304}$ The California Constitution further provides that a California public pension board's "duty to its participants and their beneficiaries shall take precedence over any other duty." 305 This rule, also known as the exclusive purpose rule, has an analogous provision in ERISA which has been interpreted to prohibit a fiduciary from "subordinating the interests of participants and beneficiaries in their retirement income to unrelated objectives." 306 The California courts have also limited authority of judicial review over whether California retirement plans have met their fiduciary duty obligations. ${ }^{307}$

One of the central provisions of ERISA as interpreted by the Department of Labor is that plans have a fiduciary duty to vote their shares

300 See Bernard S. Black, Shareholder Passivity Reexamined, 89 MICH. L. REV. 520, 552 (1990); Mark J. Roe, A Political Theory of American Corporate Finance, 91 Colum. L. REv. 10, 19 20, 24 (1991).

301 See In re Cysive, Inc., S'holders Litig., 836 A.2d 531 (Del. Ch. 2003).

302 See Emily D. Johnson, The Fiduciary Duty in Mutual Fund Excessive Fee Cases: Ripe for Reexamination, 59 DukE L.J. 145 (2009); Benjamin J. Richardson, Do the Fiduciary Duties of Pension Funds Hinder Socially Responsible Investment?, 22 BANKING \& FIN. L. REV. 145 (2007).

303 FRED REISH, BRUCE ASHTON \& STEPHANIE BENNETT, REISH LUFTMAN REICHER \& COHEN, Fiduciary Duties and OBligations in AdMinistering 457(B) Plans Under California LaW 1 (2006), available at http://www.bfsg.net/knowledgecenter/Knowledge\%20Center\%20Paper\%20$\% 20$ White\%20Paper_Fiduciary\%20Responsibilities.pdf.

$304 \quad$ ld. at 2.

305 CAL. Const. art. XVI, $\$ 17(b)$.

306 Interpretive Bulletin Relating to the Fiduciary Standard Under ERISA in Considering Economically Targeted Investments, 58 Fed. Reg. 32,607 (June 23, 1994) (codified at 29 C.F.R. § 2509.94-1(2009)).

307 Bd. of Ret. v. Santa Barbara County Grand Jury, 58 Cal. App. 4th 1185, 1193 (1997) ("Proposition 162 removed the Legislature's authority to meddle in the Board's investment decisions and it established that the Board's primary obligation was to its members and beneficiaries. Proposition 162 did not insulate pension boards from judicial oversight." (internal citations omitted)]. 
in the best economic interests of the plan participants, ${ }^{308}$ defined to exclude the interest a participant may have in minimizing downsizing by a firm in which the retirement plan is investing.

TARP is a program intended to minimize the cost of the bailout to the taxpayer by permitting the government to participate in the equity upside of bailed-out banks. Thus administration of the TARP program equity is similar in nature to the administration of a retirement plan. The Treasury has also noted that it plans to place its common equity in Citigroup, as well as investments in the Treasury's new CAP, into a trust set up to manage the government's investments, with the objective of the trustees being to protect and create value for the taxpayer as a shareholder over the term of the Treasury's TARP holdings. ${ }^{309}$ As the Author has testified before the House Oversight Committee, the terms of that trust do not adequately ensure fiduciary duties are met. 310

The Treasury's deal sheet for the Citigroup conversion indicates that the trust in which it will hold the common equity will be subject to the EESA that appropriated the TARP money. ${ }^{311}$ EESA's stated objectives are potentially conflicting. ${ }^{312}$ Thus a trust subject to this statement of purpose of the EESA will presumably be free to vote shares in favor of interests that threaten the long-term health of the bank in which the Treasury is invested. 313

A statement of fiduciary principles is of little use, however, unless the beneficiary of those principles is able to sue its fiduciary for violations. By contrast, the Resolution Trust Corporation (RTC), established to effectuate a government bailout of the savings and loan industry, was created by enabling legislation that significantly waived sovereign immunity. It provided that the RTC may "sue and be sued in its corporate capacity in

308 See Employee Retirement Income Security Act of 1974, 29 U.S.C. 404(a)(1) (2006); Interpretive Bulletin Relating to the Exercise of Shareholder Rights and Written Statements of Investment Policy, Including Proxy Voting Policies or Guidelines, 29 C.F.R. § 2509.08-2 (2009).

309 U.S. Dep'T of Treasury, Treasury White Paper: The Capital Assistance Program and

ITS ROLE IN THE FINANCIAL STABILITY PLAN 3 (2009), available at http://www.treasury.gov/press/releases/reports/tg40_capwhitepaper.pdf; see also Press Release, U.S. Dep't of the Treasury, supra note 276 , at 3.

310 Verret Testimony, supra note 147.

311 See U.S. Dep't of Treasury, Summary of Mandatorily Convertible Preferred Stock ("CONVERTIBLE PREFERRED") TERMS 3 (2009), available at http://www.treasury.gov/press/releases/reports/tg40_captermsheet.pdf (summarizing the terms of preferred stock issuance under the CAP).

312 Emergency Economic Stabilization Act of 2008, Pub. L. No. 110-343, div. A, 122 Stat. 3765 (to be codified at 12 U.S.C. $\$$ 5201) (articulating four principal purposes: "to ensure that such authority and such facilities are used in a manner that (a) protects home values, college funds, retirement accounts, and life savings; (b) preserves homeownership and promotes jobs and economic growth; (c) maximizes overall returns to the taxpayers of the United States; and (d) provides public accountability for the exercise of such authority").

313 For a more thorough examination of the incentives facing such a group of trustees, see J.W. Verret, Bailing Out the Bailout, SETON HALL L. REV. (forthcoming 2010) (on file with the Yale Journal on Regulation). 
any court of competent jurisdiction." 314 Plaintiffs were also permitted to sue the RTC in state court. 315 Therefore, it would not be without precedent for the Treasury to establish a code of fiduciary duty which defines its obligations to taxpayer beneficiaries of TARP as well as other shareholders in TARP banks. ${ }^{316}$

\section{B. Frozen Options}

My second proposal to limit the inherent drawbacks to the Treasury holding common equity, while also letting the taxpayer participate in the benefits of the bailout and thereby minimizing the cost of TARP, is to issue to the Treasury something I call frozen options. These are options to purchase common stock that governments are not permitted to exercise, but which subsequent purchasers in the market are permitted to exercise. This rests on the argument noted previously that holding common equity is not a necessary part of the bailout. ${ }^{317}$

31412 U.S.C. $\$ 1441 \mathrm{a}(\mathrm{b})(9)$ (E) (2006); see also L.E. Creel, III, Litigation Against the Resolution Trust Corporation, in RESOLUTION TRUST CORPORATION: BANKRUPTCIES, LIQUIDATIONS, AND SALES OF ASSETS 91 (1990). The RTC's enabling legislation further subjected the RTC to Chapter 5 of Title 5 of the U.S. Code, the Administrative Procedure Act, which is the source for open rulemaking requirements that permits the public to participate and oversee administrative rulemaking.

315 See Jeffrey S. Rosenblum, The RTC's Quest for Exclusive Federal Court Jurisdiction Under FIRREA, 24 MEMPHIS ST. U. L. REV. 725, 725 (1994).

316 This would have the mutually reinforcing effect of assuring other shareholders that it does not intend to use its power as a shareholder to take action that will result in damage to the long-term health of TARP participants. This would (1) assist banks in raising private capital to enhance their TCE ratios to reflect private shareholder interest in obtaining the residual profits of a bank's loan risk and (2) increase the value of the Treasury's TARP shares, thus helping it to minimize the cost of TARP to the taxpayer.

317 Linus Wilson and Yan Wendy Wu offer a different view for using common equity in bank capital injections. Wilson and Wu construct a model demonstrating that purchases of common stock are always the most efficient method for governments to induce new lending by banks, as opposed to purchases of preferred stock, notes, or other instruments, or public-private partnerships. They justify the use of common equity over preferred stock not by the effect that one or the other will have on a firm's ability to obtain equity capital from the market, but by the incentives that infusions of common equity give banks to lend compared to the incentives that a similar injection of preferred stock offers. One of the assumptions in the model underlying Wilson and Wu's view is that governments are unable to contract with firms directly regarding their lending policy. Linus Wilson \& Yan Wendy Wu, Common (Stock) Sense About Risk-Shifting and Bank Bailouts, 24 Fin. MARKETS \& PORTFOLIO MGMT. 3, 4 (2010). That assumption does not hold, however, when the government holds equity control over banks, because the government will then have the ability to use its powers as a shareholder to influence corporate policy with the same effect as contracting over the firm's lending policy. Wilson and Wu compare the incentive effects of using preferred stock, common equity, or direct purchases of troubled assets on banks, and finds that each of them involves a subsidy to the bank to induce subsequent lending. Id. at 4,47 . They conclude that common equity purchases require the lowest subsidy to induce efficient lending, on the basis that banks voluntarily participating in a bailout are less likely to shift inefficient levels of risk to common shareholders than to creditors. Id. at 48. Accepting the conclusion and method of this analysis should not necessarily lead us to believe common equity is the preferable method for a government bailout. This Article argues that despite common stock recapitalizations, governments are pressured to use the control powers of their common stock to require inefficient changes in corporate policy, including lending, employment practices, M\&A decisions, facility 
With respect to the banking and financial sector, the federal government, post-TARP, has three basic sources of authority. It regulates industry lending and financial practices. It often, though not always, serves as the lender of last resort in the event other sources of liquidity dry up. And now, as this Article has demonstrated, it also holds an equity interest in TARP participants. Some may argue that the first two powers permit the government the sufficient ability that analysis of shareholder voting powers is rendered moot, and thus a focus on shareholder equity is unimportant.

With respect to the technical problems that accompany TARP ownership described above, that argument is not particularly useful. The securities laws and corporate law are built around the powers and responsibilities of equity stockholders. Optionholders do not have the power to sue under the Delaware Code, nor can they join in federal class action litigation. Option holders have never been deemed control shareholders by virtue of their option holdings. As such, getting rid of the federal government's equity holdings would go a long way toward undermining the factors that make the federal government a control shareholder.

With respect to the theoretical aspects of this Article, the argument becomes a little more interesting. It is true that the federal government obtains substantial power through its regulatory authority and as a liquidity provider. However, with respect to its regulatory authority, industry also has substantial power to push back against its regulator through the lobbying and political interaction process. But when the government becomes both a regulator and a shareholder, the power it holds inside the company and the power it holds from outside interact in a cumulative way. The government can stop a company from pushing back against new regulation through exercise of its new ability to select, directly or indirectly, the board of directors and chief executives. It can also give preferential regulatory treatment to the companies it does control to help them gain market share.

On the issue of liquidity provisions, we have seen the government demonstrate that, though generous, its flexibility as a lender of last resort is not without limit. Further, the power that the federal government may obtain as a lender will also depend on existing economic conditions. As the prospect for needing a government loan in the future becomes more

closures, and the like, that will alter Wilson and Wu's analysis and lead to the conclusion that the incentive distortions from government-held common equity are greater because of the control element of the common equity. This will subsequently damage the value of a bank's shares, minimizing its ability to obtain subsequent capital from private markets and increasing the odds of subsequent need for additional bailout and government guarantee. 
remote, the power afforded to the government by its status as lender of last resort will continue to wane. 318

Giving government equity upside as part of a bailout dilutes the interest of equityholders, imposing a penalty on them for investing in a business that needed rescue. Bank equityholders are forewarned: invest more resources to monitor the business decisions of your investments, or else. But there are many ways to participate in the upside of a company. If you let the Treasury choose the method, it will inevitably reach for the one with the most political power. Frozen options are the best way to limit these challenges to the bailout.

\section{Sales Plan}

My final recommendation is that the Treasury should establish a sales plan for its TARP frozen options, similar to the $10 \mathrm{~b} 5-1$ sales plans that executives file with the SEC. ${ }^{319}$ The Treasury should adopt a similar plan that follows the same requirements of the SEC's exemption, in spite of its exemption from the Exchange Act.

The first requirement of the SEC's sales plan exemption is that the written 10b5-1 plan must have been crafted before the individual creating the plan became aware of any material non-public information. ${ }^{320}$ This

318 That is not to say that the powers of the government as guarantor of a company's obligations cannot result in dramatic market distortions. The market for corporate debt imposes a certain discipline on a company's management by requiring higher interest payments if it perceives a company's business position as overly risky. See WALLISON, supra note 25 , at 1 . When the government guarantees the private institution's debt, however, this discipline is muted. The financial institution can continue to borrow money and invest it in riskier projects without a need to balance that against an increasing interest rate for the funds it borrows itself or a need to offer up more collateral for the debt. This is because private markets tend to regard U.S.-backed private debt similarly to U.S. debt itself, and investors assume that treasuries carry no risk of default. See Peter J. Wallison, Regulating Fannie Mae and Freddie Mac: Now It Gets Serious (Continued) 4 (Am. Enter. Inst. for Pub. Policy Research, Financial Services Outlook Series, 2005), available at http://www.aei.org/outlook/23187. Thus, U.S.-backed private debtors can continue to borrow at interest rates effectively subsidized by the government's guarantee. This was particularly true for Fannie and Freddie, even through the government explicitly warned that it would not guarantee the GSEs' debt, despite eventually doing so. See WALLISON, supra note 25, at 2; Zachary A. Goldfarb, Treasury Secretary Backs Fannie, Freddie Reshaping, WASH. POST, Mar. 24, 2010, http://www.washingtonpost.com/wp-

dyn/content/article/2010/03/23/AR2010032303993.html. In effect, the markets called their bluff, and the markets ended up being right. This discipline is further distorted by the fact that the government actually has motives to require the guaranteed institution to take risks that present negative value propositions for the company.

319 In 2001, the SEC adopted an exception to insider trading liability to permit persons to make trades while in possession of material non-public information, as long as the information was not a part of the person's decision to trade. Brandon C. Parris, Rule 10b5-1 Plans: Staying Out of Trouble, Bus. L. TODAY, May/June 2008, at 21.

32017 C.F.R. $\$ 240.10$ b5-1(c)(1)(i)(A) (2009). The Treasury could appoint a nonpartisan panel of experts to design its plan, and negotiate with the various TARP participants concerning whether they will purchase the securities in advance of the date under which the Treasury has the right to sell them. In order to ensure that the panel makes its determinations on the basis only of 
may be difficult at this point, as the Treasury and the Federal Reserve are likely in possession of significant inside information. The second requirement of a 10b5-1 plan is that its terms either specify in reasonable detail the amount and price of the securities to be purchased or sold and the dates for such purchases or sales, or provide a written formula, algorithm, or computer program that determines the amount and price of the securities to be purchased or sold and the dates for such purchases or sales. ${ }^{321}$ The third requirement of a $10 \mathrm{~b} 5-1$ plan is that the terms of the 10b5-1 plan do not permit the executive to exercise any subsequent influence over how, when, or whether purchases or sales would be effected under the plan, and also that if the terms of the 10b5-1 plan permit a third party to exercise such subsequent influence, such third party does not do so at a time when aware of material non-public information. ${ }^{322}$

The Treasury should establish a clear timeline for its ownership of bank stocks through a sunset provision issued either through legislation or codified rule and subject to challenge if the Treasury later changes its mind. It should also establish a clear sales plan, similar in nature to the $10 \mathrm{~b} 5-1$ sales plans that private executives file with the SEC to prevent allegations that they have engaged in insider trading. This will prevent misuse of inside information by the Treasury (or the trust that holds the assets on behalf of the Treasury, which if staffed by Treasury personnel will also share the Treasury's immunity from insider trading rules as well as its access to inside information about the bank it owns).

publicly available information, it should be required to disclose the information that the Treasury and the Federal Reserve share with it and that it uses to craft the sales plan.

321 Id. $\$ 240.10 \mathrm{~b} 5-1(\mathrm{c})(1)(\mathrm{i})(\mathrm{B})(1)-(2)$. This measure could be informed by the publicly available results of the stress tests. It could even be crafted such that the algorithm delays trades until certain measures of a company's health or profitability substantially improve, or until such time as the formulas indicate that the government should close out its investment and liquidate its holdings.

322 Id. $\S 240.10 \mathrm{b5}-1(\mathrm{c})(1)(\mathrm{i})(\mathrm{B})(3)$. This requirement would need some implementing legislation to adequately ensure its effectiveness. Such legislation should specify a significant penalty for the Treasury if it violates this requirement. One simple way to guarantee a penalty would be to lift the government's immunity under section 3(c) of the Exchange Act Alternatively, the legislation implementing this plan could specify a penalty for its violation, such as a rescission for any affected purchaser of securities from the government, including TARP recipients repurchasing their own securities. 